\title{
Information Sharing and Rating Manipulation
}

\author{
Mariassunta Giannetti \\ Stockholm School of Economics, CEPR, and ECGI \\ José María Liberti \\ Driehaus College of Business, DePaul University and Kellogg School of \\ Management, Northwestern University
}

\section{Jason Sturgess \\ Queen Mary University of London}

\begin{abstract}
We show that banks manipulate borrowers' credit ratings before sharing them with competing banks. Using a unique feature on the timing of information disclosure of a public credit registry, we disentangle the effect of manipulation from learning of credit ratings. We show that banks downgrade high-quality borrowers for which they have positive private information to protect their informational rents. Banks also upgrade low-quality borrowers with multiple lenders to avoid creditor runs. Our results suggest that credit ratings manipulation limits the positive effects of credit registries' information disclosure on credit allocation. (JEL G2; G14; G38)
\end{abstract}

Received April 18, 2016; editorial decision April 1, 2017 by Editor Philip Strahan.

The diffusion of information technology promises to enable the sharing of larger and finer amounts of information. By reducing information asymmetries between borrowers and banks and between banks lending to the same borrower, information sharing is expected to reduce market segmentation and to enhance access to credit for creditworthy borrowers (Padilla and Pagano 1997).

We are grateful to Phil Strahan (the editor), two anonymous referees, Amar Bhide, Hans Degryse, Andrew Hertzberg, Tullio Jappelli, Marco Pagano, Fausto Panunzi, Daniel Paravisini, Mitchell Petersen, Amit Seru, Ed Van Wesep, Teng Wang, Alminas Zaldokas and seminar participants at the American Finance Association Annual Meeting, the Utah Winter Finance Conference, the $12^{\text {th }}$ Corporate Finance Conference at the University of Washington in Saint Louis, the Conference on The Economics of Credit Rating Agencies, Credit Ratings and Information Intermediaries at Tepper School of Business (Carnegie Mellon University), the Financial Intermediation Research Society Conference, the HKUST Finance Symposium, the 7th European Banking Center Conference at Tilburg University, the 12th CSEF-IGIER Symposium on Economics and Institutions, the Financial Management Association Conference, Oxford University, Purdue University, the PBC School of Finance of Tsinghua University, Queen Mary University, the University of Melbourne, Universitat Pompeu Fabra, and Stockholm School of Economics for their comments. Giannetti acknowledges financial support from the Swedish House of Finance and the Bank of Sweden Tercentenary Foundation. Supplementary data can be found on The Review of Financial Studies web site. Send correspondence to Mariassunta Giannetti, Stockholm School of Economics, Box 6501, Sveavagan 65, S-11382, Stockholm, Sweden; telephone: +46-8-736 9607. E-mail: mariassunta.giannetti@hhs.se.

(C) The Author 2017. Published by Oxford University Press on behalf of The Society for Financial Studies. All rights reserved. For Permissions, please e-mail: journals.permissions@ oup.com. doi:10.1093/rfs/hhx050 
Information sharing, however, is also known to increase competition in credit markets (Pagano and Jappelli 1993; Padilla and Pagano 1997). For this reason, banks may not necessarily agree to share information about their clients, and private solutions for sharing information, such as credit bureaus, may not emerge. Public credit registries, to which banks must provide information, are considered a valid substitute (Jappelli and Pagano 2002).

Public credit registries are common across the world and have a variety of designs. Lenders are often required to provide not only any negative information about borrowers, such as delinquencies and defaults, but also information about loans in good standing, including borrowers' credit ratings. ${ }^{1}$ Surprisingly, in existing cross-country studies, evidence that the adoption of public credit registries affects the supply of credit is ambiguous (Djankov, Mcliesh, and Shleifer 2007; Peria and Singh 2014).

We show that banks have incentives to manipulate private information included in their borrower credit ratings before sharing it, and that this limits the positive effects of information sharing on the allocation of credit. Using a unique feature on the timing of the information released, provided by the expansion of the public credit registry in Argentina, we show that banks downgrade their high-quality borrowers before disclosing the rating information in order to safeguard their informational monopoly. Banks also tend to upgrade lowquality borrowers with multiple lenders to avoid creditors runs, which could impair the borrower's financial situation and ability to repay any loan.

To the best of our knowledge, this is the first paper to highlight that banks' incentives may impair the effectiveness of public credit registries. In general, we highlight that making information public may negatively affect the quality of information if information disclosure feeds back on an agent's payoff. This has wider policy implications for the debate about how information should be disseminated in financial markets, something we discuss in the conclusions.

Our tests exploit a unique feature of the Argentinian public credit registry, which was reformed in 1998 thanks to the adoption of CD-ROMs. This adoption decreased the cost of distributing large amounts of information. The way this reform was implemented enables us to observe a borrower's credit rating, that is, a score capturing the loan officer's judgment of the customer's prospects (including private information) in three different periods: (1) a preannouncement period, before the reform, when banks reported information to the Central Bank, but expected the credit ratings to remain private; (2) an interim period following the reform announcement in April 1998, but preceding its implementation in July 1998; and (3) a post-expansion period following the implementation of the reform, when information about the borrowers'

1 With the introduction of the Basel II framework, lenders use internal ratings to determine capital requirements. The ratings disclosed in public credit registries typically are different from the Basel II ratings used for capital requirements. 
credit ratings was actually shared. ${ }^{2}$ We can thus ask whether banks abnormally modified their borrowers' credit ratings in the interim period after the reform announcement but before having to share the information with other banks. By focusing on the interim period, we are able to isolate a bank's manipulation of credit ratings from learning from the disclosure of other banks.

Existing theories help us to formulate hypotheses on the direction in which banks would have incentives to manipulate borrowers' credit ratings. These hypotheses allow us to test whether banks indeed manipulate ratings to conceal their risk assessment of borrowers from competitors.

The first set of tests we perform builds on the influential papers of Sharpe (1990) and Rajan (1992), who show that banks may have an informational monopoly on their high-quality clients. High-quality borrowers may be "informationally" captured by their lending banks because they face difficulties in conveying information about their creditworthiness to other lenders. These effects have been widely documented in the literature even for firms close to the initial public offering stage (Schenone 2010) and are expected to be stronger for borrowers that entertain exclusive relationships with their banks.

Under these conditions, we expect that public credit registries, which force banks to share information about the borrowers, should mitigate adverse selection problems and enhance credit access for high-quality borrowers. However, truthfully revealing positive private information about borrowers might erode banks' informational rents and ultimately bank profits. Banks' incentives would thus be to downgrade high-quality borrowers before sharing information with other banks.

The incentives of banks lending to low-quality borrowers with multiple relationships are opposite. First, these banks do not enjoy high informational rents because borrowers are low-quality and would have to pay a high interest rate on their loans even in a symmetric information environment. ${ }^{3}$ Therefore, the banks have no incentives to downgrade them. On the contrary, the revelation of negative public information about borrowers may induce a creditor run as highlighted by Corsetti et al. (2004) and Hertzberg, Liberti, and Paravisini (2011). Observing a negative rating for a given borrower, lenders may revise upwards the probability that the bank sharing the negative rating will withdraw credit and in response cut their own loans. Thus, in order to avoid a creditor run, banks should have an incentive to upgrade low-quality borrowers that have relations with multiple lenders.

In addition to exploiting these theoretical predictions that differ for different subsamples of borrowers to identify rating manipulation, our empirical setting

2 Hertzberg, Liberti, and Paravisini (2011) exploit the same setting to provide evidence for the consequences of lender coordination problems on loan amounts.

3 Banks also may clearly enjoy rents on low-quality borrowers because of a lack of competition in the credit market. However, they do not enjoy an informational rent because low-quality borrowers are not hurt from being pooled with other borrowers. 
allows us to design a difference-in-differences methodology that further mitigates any concerns that our findings may be driven by aggregate shocks that systematically affect borrowers during the various phases of the reform.

Before the 1998 reform of the public credit registry, even though it collected information about all borrowers, the Central Bank shared only information about borrowers whose total outstanding debt was above $\$ 200,000$ and borrowers in default with other lenders because distributing information for large numbers of small debtors would have been prohibitively costly. However, the adoption of CD-ROMs dramatically reduced the cost of distributing information and eliminated the need for the $\$ 200,000$ threshold. Thus, in April 1998 , it was decided that credit information for roughly 540,000 borrowers below the threshold would be publicly disclosed. The reform was implemented in July 1998.

We can thus test whether banks exhibit an abnormally high propensity to downgrade high-quality borrowers with total borrowing less than $\$ 200,000$ in the interim period between the announcement and implementation of the reform, using high-quality borrowers above the \$200,000 threshold as a control sample. We can also test whether the propensity to downgrade highquality borrowers below the threshold is highest for banks with an information advantage such as local banks or those that entertain exclusive relationships with the borrowers, which presumably enjoy the highest informational rents, for relationships with opaque borrowers, for which adverse selection is greatest, and for borrowers in states with more bank branches, which are more likely to be poached following a decrease in information asymmetry. Similarly, we test whether nonexclusive lenders upgrade low-quality borrowers below the $\$ 200,000$ threshold during the interim period to a larger extent than those in the control sample.

To abstract from the effects of unobserved borrower heterogeneity, we restrict the analysis to borrowers whose pre-announcement total borrowing was between \$150,000 and \$200,000 (treatment group) and borrowers whose preannouncement total borrowing was between $\$ 200,000$ and $\$ 250,000$ (control group), who we show to be similar in terms of observable characteristics (excluding total borrowing), and perform a number of robustness tests.

Our tests provide unambiguous evidence that banks manipulate borrowers' credit ratings in the interim period before making them public. We show that banks downgrade their high-quality borrowers before sharing their credit ratings with other banks and that this tendency is entirely driven by local banks, that is, by informationally advantaged banks (Berger et al. 2005). In the same vein, we find that exclusive lenders, who are also expected to have private information about their borrowers, are more likely to downgrade high-quality borrowers before sharing their ratings. Opaque borrowers and borrowers in more competitive credit markets are more likely to be downgraded. This is consistent with lenders' desire to protect their informational rents in credit markets in which competitors are more likely to poach customers once 
information is shared. We also find that banks that are lenders to low-quality borrowers with multiple relationships have a tendency to upgrade them before making their ratings public as is consistent with a desire to avoid a creditor run.

As a consequence of ratings manipulation, ratings become less informative after the announcement of the public credit registry extension. Borrowers that were rated as the safest were less likely to default before the reform; borrowers that were rated as relatively riskier are instead less likely to default after the reform. Consequently, ratings manipulation might limit the extent to which public information shared in a registry enhances access to credit.

We also examine the effects of the public credit registry expansion on the affected borrowers' bank relationships. We show that banks update their ratings to take into account other lenders' ratings. Consequently, the expansion of the public credit registry facilitates new lending to single-lender borrowers with the highest credit ratings. Importantly, single-lender borrowers that have been strategically downgraded do not enjoy these benefits. The number of bank relationships of multiple-lender borrowers also increases, which implies that informationally disadvantaged intermediaries that provide smaller transactional loans may benefit from the credit registry. These results suggest that, notwithstanding the ratings manipulation, the credit registry enhanced access to credit by reducing adverse selection for the most informationally disadvantaged lenders. However, borrowers that were downgraded in the interim period do not appear to reap the benefits of the credit registry expansion, indicating that the strategic downgrades are effective in preserving banks' informational rents.

This paper belongs to a growing literature exploring the impact of information sharing on access to credit. Existing papers show that pooling of information about borrowers' credit histories decreases delinquencies (DoblasMadrid and Minetti 2013; Sutherland 2015) and enhances creditworthy borrowers' access to credit (Musto 2004; Gonzales-Uribe and Osorio 2014). All these papers consider private credit bureaus and the sharing of information about loan repayments. While the sharing of information about borrower quality is contemplated by existing theories (e.g., Padilla and Pagano 1997) and common in public credit registries across the world (Powell et al. 2004; Brown, Jappelli, and Pagano 2009), there is scarce empirical evidence on the effects of this dimension of information sharing.

Liberti, Seru, and Vig (2016) show that, after the expansion of the Argentinian credit registry, a large international lender made some use of other banks' ratings for credit allocation and organizational design. This is consistent with our findings. Hertzberg, Liberti, and Paravisini (2011) also exploit the same expansion of the Argentinian public credit registry as we do and show that, before the public release of information, fearing a creditor run, lenders strategically decreased their credit exposure to low-quality borrowers with multiple bank relations. We highlight that lenders strategically manipulate the information they release, a complementary strategic effect of the public release 
of information, which is important for an effective design of public credit registries.

Our findings are also important for the growing literature exploring the role of credit ratings in the financial system and the incentives of credit rating agencies. Existing literature has highlighted that because of competition among credit rating agencies and conflicts of interest arising from credit agencies being paid by issuers, credit ratings may overstate issuers' creditworthiness (see, for instance, Bolton, Freixas, and Shapiro 2012; Efing and Hau 2015; Griffin, Nickerson, and Tang 2013). Others have shown that banks may understate credit risk in order to be able to securitize (Rajan, Seru, and Vig 2010, 2015) or lower their Basel II capital requirements (Carey 2012; Plosser and Santos 2014; Begley, Purnanandam, and Zheng 2015). We highlight that incentives to manipulate ratings exist also when ratings do not impact capital requirements because the ratings affect credit market competition through informational rents and potential loan losses in case of multiple lenders.

\section{Theoretical Background}

In existing studies, public credit registries appear to have more limited effects on the allocation of credit in comparison to private credit bureaus, in which banks voluntarily share information (Love and Mylenko 2003; Djankov, Mcliesh, and Shleifer 2007; Peria and Singh 2014).

We argue that information manipulation may limit the positive effects of public credit registries. Even if regulators audit the information provided to the credit registry, banks may manipulate nonverifiable information about borrowers, such as credit ratings, before reporting it to the credit registry. Not only would this behavior be consistent with banks' incentives but it also would be difficult for government authorities to prevent because the reported information is difficult to verify. Detecting any manipulation of the ratings reported to the registry is likely to be particularly difficult if ratings concern opaque borrowers, such as small entrepreneurial firms.

Existing theories allows us to formulate stringent hypotheses on the direction of manipulation. As we discuss below, these predictions differ for different groups of borrowers.

It follows from the influential papers of Sharpe (1990) and Rajan (1992) that banks have weaker incentives to share information about borrowers on which they have positive private information. High-quality borrowers face an adverse selection problem if they approach outside lenders, who expect many low-quality borrowers, rejected by their previous banks, to approach them. This adverse selection problem creates an informational rent for current lenders and allows lending banks to charge interest rates higher than the ones that would prevail in a competitive environment with no asymmetric information. The same adverse selection problem that allows banks to charge excessive interest rates prevents high-quality borrowers from reacting to a strategic downgrade 
(if they observe the change in credit rating) as claims of being unfairly rated would not be verifiable by outsiders.

A bank is more likely to have private information about a high-quality customer if it entertains an exclusive relationship. The informational monopoly is otherwise at least partially eroded by the fact that many lenders to the same borrower are likely to observe the same information. Supporting the idea that firms with multiple relations are less subject to an informational lockin from their lenders, Ioannidou and Ongena (2010) show that these firms obtain smaller cuts in interest rates if they manage to switch to an outside bank. Furthermore, Ongena and Smith (2001) and Farinha and Santos (2002) find that borrowers with multiple relationships entertain shorter relationships with their banks, suggesting that they are less likely to be locked into these relationships. These findings indicate that multiple relationships soften hold-up problems. Therefore, exclusive lenders should have stronger incentives to manipulate downward the ratings of high-quality borrowers before sharing information in the credit registries.

Existing literature also highlights that different types of banks have different information about their borrowers. Thanks to their flat organizational structures, local banks have the highest level of private information about their borrowers (Berger et al. 2005), while foreign banks base their lending decisions on easyto-verify, mostly public information (Mian 2006; Giannetti and Ongena 2009). Similarly, local banks being specialized in lending to a particular region are expected to have more private information than banks active nation-wide (Berger et al. 2005). We thus expect that the incentives to manipulate ratings and to downgrade high-quality borrowers should be stronger for local banks, which have more private information and should have more to lose in terms of informational rents.

Incentives for lenders to low-quality borrowers are different. Lenders to lowquality borrowers do not enjoy informational rents because the credit risk of these borrowers warrants a high interest rate. Making negative information about the borrower public may lead other lenders to withdraw their loans or to increase the interest rate, causing financial distress for the borrower and impairing the value of the loan of all banks, including the one disclosing negative information (Hertzberg, Liberti, and Paravisini 2011). Thus, if their low-quality clients have multiple lenders, banks have an incentive to upgrade borrowers' ratings before sharing them.

We expect this mechanism to hinge to a lesser extent on the extent of private information of a bank. If lenders interpret a negative credit rating as a signal that the bank issuing the negative rating will restrict or withdraw credit from the borrower, then all other lenders may want to cut their loans right away irrespective of their private information about the borrower. To avoid creditor runs, and the negative feedback effects that these may have on their balance sheets, all banks (not only the most informationally advantaged) are expected to strategically upgrade borrowers with multiple lenders. 
Importantly, the incentives to manipulate ratings are opposite for banks involved in relationships with relatively high- and low-quality borrowers. They also differ depending on the type of bank and on whether the borrower has multiple banks. Therefore, any evidence supporting the conjecture that lenders manipulate the credit ratings before making them public would be difficult to explain using omitted factors, asymmetric shocks, or mechanisms that involve the systematic review and update of ratings before their release. Below, we describe an institutional context that lends itself naturally to test whether banks manipulate ratings before making them public.

\section{Institutional Setting and Empirical Implementation}

\subsection{The credit registry and its reform}

Argentina's public credit registry was established in 1991 and covers every firm and entrepreneur that obtains credit from a financial institution. Its design is typical of public credit registries around the world (Powell et al. 2004; Brown, Jappelli, and Pagano 2009). Therefore, any conclusions of our study on whether nonverifiable information, such as credit ratings, can be shared without manipulation has broad applicability.

All financial institutions active in Argentina are required to report to the Central Bank the amount of the loan, the amount of collateral pledged, and each borrower's rating. Ratings are provided as an integer ranging from one to five, where one represents the highest creditworthiness and five the lowest. The bank has full discretion in assigning the borrower a one or a two rating based on its private assessment of the borrower's repayment prospects. Ratings ranging from three to five are mechanically determined based on the borrower's repayment status. The bank has to assign a rating of three if the borrower has been delinquent for more than 90 days or, in general, if the borrower is considered to have high default risk. Ratings of four and five are assigned to borrowers that have been delinquent for over 180 days and which have had collateral seized or are in bankruptcy. These borrowers can be considered to be in default. Therefore, banks have to set aside more capital when assigning ratings of three or higher, while granting a rating of one or two has no implications for capital requirements.

While discretional, ratings of one or two are informative. In our sample, borrowers with a rating of two have a $21 \%$ probability of default over the subsequent six months, significantly higher than the $3.6 \%$ default rate of borrowers with a rating of one. Also lenders often attribute different ratings to the same borrower indicating that ratings include private information. ${ }^{4}$

\footnotetext{
4 Figure IA. 1 in the Internet Appendix shows the within-borrower standard deviation in credit ratings. Throughout the sample period some disagreement indicates that lenders have private information. However, disagreement is greatest when the ratings are private, that is, for treatment borrowers in the pre-expansion period. Table IA.1 in the Internet Appendix formally tests that banks update their ratings after observing other lenders' ratings.
} 
Up to 1998 , the Central Bank provided, using monthly magnetic tapes, information about the most recent cross-section of borrowers with a total amount of loans above a $\$ 200,000$ threshold to financial institutions and credit rating agencies making requests of it. ${ }^{5}$ The Central Bank also provided information about borrowers with a default rating of three or higher regardless of the amount of their loans. In April 1998, the Central Bank announced the switch to CD-ROMs, which substantially lowered information sharing costs and made it feasible to distribute monthly information about all borrowers even the ones with total loan amounts below the $\$ 200,000$ threshold and with ratings lower than three.

Since lenders could always infer any borrower's amount of loans from other lenders from financial statements and tax returns, and delinquencies and defaults were shared in the registry, the reform made available the credit ratings assigned by existing lenders to nondelinquent borrowers (that is, borrowers with one and two ratings) with a total amount of loans below the $\$ 200,000$ threshold. $^{6}$

We thus focus on banks' incentives to manipulate the reported one and two ratings. Banks should have scope to alter the one and two ratings, subject to the constraint of not raising suspicions with the Central Bank, which audits a random sample of each bank's portfolio monthly. In this way, banks can muddle waters and maintain their information advantage for some borrowers.

The expansion of the credit registry was announced in April 1998 and implemented in July of the same year. Thus, the ratings of the first quarter of 1998 for borrowers with total borrowing below the $\$ 200,000$ threshold are the ones that financial institutions reported to the Central Bank when they did not observe other banks' ratings and did not expect other banks to ever observe their assessment of the borrowers. These ratings capture the financial institutions' private information. Since they were expected to remain the exclusive knowledge of the Central Bank, they do not capture the strategic behavior of financial institutions.

In April 1998, institutions learned that their ratings would be shared with other existing and potential lenders. ${ }^{7}$ However, until July of the same year, they did not observe other banks' ratings. Any systematic changes in the ratings of borrowers with total borrowing below the $\$ 200,000$ threshold occurring during this three-month period, to which we refer to below as the interim period, only can be driven by the anticipation that other banks will observe the ratings. Systematic changes cannot be explained by the effect of learning from

5 The Central Bank aggregated all loans outstanding to a borrower for each bank and made the information public if the total loan amount was $\$ 200,000$ or higher.

6 Also, borrowers have strong incentives to reveal whether they have other lenders in the contracting phase to decrease their interest rate.

7 Borrowers may learn their own ratings when they ask for a new loan. However, if they are informationally captured, they cannot ask for an upgrade to the same extent that they cannot successfully ask for a lower interest rate. 
other financial institutions' assessment of the borrower's creditworthiness, as information had not yet been shared. ${ }^{8}$

Clearly, shocks may affect borrowers and lead to changes in the banks' risk assessment. For this reason, we design an empirical methodology that allows us to abstract from the effects of shocks, learning, and borrower unobserved heterogeneity.

\subsection{Empirical framework}

The stages of the reform implementation and the different theoretical predictions for banks' incentives to manipulate the ratings of borrowers with single and multiple relationships and high- and low-quality borrowers allow us to identify the effect of information sharing on rating manipulation.

We start by considering the effect of the announcement of the reform on the borrowers of highest credit quality that entertain a single bank relationship. As argued in Section 2, under these conditions, banks are likely to enjoy informational rents. To preserve their informational monopoly, banks may thus be inclined to strategically downgrade high-quality borrowers before sharing their ratings. We expect this propensity to be predominantly driven by local banks, which are better than other lenders at collecting information about small, opaque borrowers and should therefore have a stronger informational advantage.

We then extend the sample to high-quality borrowers with single and multiple relations and test that the propensity to downgrade is indeed lower for borrowers that have multiple relationships and are therefore less informationally captured by their lending banks.

To control for the fact that high-quality borrowers may be subject to negative shocks that lead to downgrades, we consider that the ratings of borrowers with total borrowing above $\$ 200,000$ were already public. To the extent that borrowers above and below the $\$ 200,000$ threshold are similar, any abnormal downgrades for borrowers below the threshold (the treatment group) than for borrowers above the threshold (the control group) are expected to capture strategic downgrades.

Most of our tests focus on the subsample of borrowers with a single relationship and rating of one for strategic downgrades (or on borrowers with multiple relationships and a rating of two for the strategic upgrades) without comparing borrowers with single and multiple relationships or different ratings. Thus, differential exposures of single- and multiple-lender borrowers, or of

\footnotetext{
8 Strategic manipulation can achieve the objective of fudging information even if other lenders observed the history of the ratings. In the interim period, at least some downgrades from one to two might have been driven by the arrival of negative information. Therefore, potential lenders were unable to distinguish between actual and strategic downgrades and to offer loans to downgraded borrowers with a two rating at the same favorable conditions as to borrowers with a one rating. This weakened competition for downgraded borrowers is consistent with the empirical evidence in Table 9 that these borrowers did not experience any benefits from the credit registry.
} 
borrowers with different credit ratings, to economic shocks cannot drive our findings.

Our identifying assumption is that, within each group of borrowers, borrowers with total borrowing below and above the $\$ 200,000$ threshold are subject to similar shocks. For this reason, to abstract from any effects of borrowers' heterogeneity, which could lead to downgrades, we consider only borrowers that in the pre-announcement period had total outstanding loans between $\$ 150,000$ and $\$ 250,000$ and perform robustness around this interval. In what follows, we present extensive evidence corroborating our identifying assumption.

Focusing on the highest quality single-lender borrowers, for which we expect banks to enjoy the highest informational rents and to have the strongest incentives to manipulate ratings downward, we estimate the following equation:

$$
\begin{aligned}
\text { Downgrade }_{i, b, t}^{1 t o 2, s}= & \beta_{0}+\beta_{1} \text { Treated }_{i}+\beta_{2} \text { Treated }_{i} \\
& \times \text { Interim }_{t}+\beta_{3} \text { Treated }_{i} \times \text { Pos }_{t}+\xi_{t}+\lambda_{b}+\phi_{b, t}+\varepsilon_{i, t},
\end{aligned}
$$

where Downgrade $e_{i, b, t}^{1 t o 2 s}$ is a dummy variable that takes a value equal to one if a single-lender borrower $(s)$ who had received the highest credit rating of one from bank $b$ during month $t-1$ is downgraded by bank $b$ to a rating of two during month $t$. Consistent with the theoretical predictions, this variable is defined only for borrowers with a rating of one at the beginning of the preannouncement period, is equal to zero if the credit rating is one at $t$, becomes one if the credit rating is two at $t$, and drops out of the sample afterward.

In all specifications, we include a full set of time effects using month dummies $\left(\xi_{t}\right)$ and test the robustness of our findings to the inclusion of bank $\left(\lambda_{b}\right)$, banktime $\left(\phi_{b, t}\right)$, and borrower-industry-time fixed effects.

The dummy variables Interim $_{t}$ and Post $_{t}$ each take a value equal to one in the periods April-June 1998 and July 1998-June 1999, respectively. The omitted category is the period preceding the reform announcement, which goes from January 1998 to March 1998. The dummy Treated $_{i}$ takes a value equal to one if borrower $i$ 's maximum amount of total borrowing was below $\$ 200,000$ during January-March 1998 (the pre-announcement period), and was therefore omitted from the public registry prior to the expansion. We cluster errors at the borrower level. ${ }^{9}$

If banks indeed manipulate ratings to preserve their informational monopoly, we expect that $\beta_{2}>0$. We do not necessarily expect an analogous effect in the post-period, when ratings have already become public.

We develop the above framework to test whether some local banks having more private information are more inclined to manipulate than other lenders. We also explore cross-sectional differences across borrowers.

Next, we test whether a rating of two is associated with a lower probability of default for borrowers in the treatment group (in comparison to the

9 Table IA.2 in the Internet Appendix shows that the results are invariant if we cluster errors at the bank level. 
control sample) after the public credit registry has been announced. If banks indeed manipulate the rating of high-quality borrowers downward, we expect borrowers with a rating of two to be more likely to default before the announcement, when the rating was more likely to reflect the bank's negative information.

The theories described in Section 2 also imply that fearing a creditor run, banks may have an incentive to upgrade low-quality borrowers with multiple relationships. To test whether there is any evidence of strategic upgrades, we estimate a model analogous to (1), where the dependent variable is Upgrade $_{i, b, t}^{2 t o 1, m}$, which is defined only for multiple relationship borrowers with a rating of two at the beginning of the pre-announcement period, is equal to zero if the credit rating is two at $t$, becomes one if the credit rating is one at $t$, and drops out of the sample afterward. If banks indeed manipulate the borrowers' ratings before making them public, we expect that treatment group borrowers are more likely to be upgraded in the interim period if they have multiple relationships.

\section{Sample and Descriptive Statistics}

We condition on borrowers that had relationships with banks in January 1998 and then track these borrowers through the 3-month pre-announcement period, the 3-month interim period, and the 12-month post-registry expansion. We assign borrowers with total borrowing between $\$ 150,000$ and $\$ 200,000$ in the pre-announcement period to the treatment group and borrowers with total borrowing between $\$ 200,000$ and $\$ 250,000$ during the same period to the control group.

Table 1 presents descriptive statistics for the sample of treatment and control borrowers. The sample includes 1,764 borrowers, of which 702 have an exclusive relationship with a bank in the pre-announcement period, and 2,865 bank-borrower relationships. Of the 1,764 borrowers, $389(1,375)$ are treatment (control) borrowers.

Panel A of Table 1 presents descriptive statistics for all, treatment, and control borrowers during the pre-announcement period with the aim of validating our identifying assumption. We further sort on the exclusivity of the lending relationship. Examining treatment and control groups, the mean loan for treatment (control) borrowers is for $\$ 113,167$ (\$135,155), with total borrowing of $\$ 179,517$ (\$223,562). Overall, the two groups are similar in terms of collateral, credit rating, number of banks, size (as measured by a categorical variable assigning each borrower to one of six categories based on number of employees), and importantly the proportion of borrowers with exclusive relationships. The proportion of urban borrowers is only slightly higher in the control group.

We find similar evidence that treatment and control groups are comparable (except for lending amounts) for both exclusive and multiple-relationship borrowers, respectively. Figure 1 shows that the distribution of treatment and control borrowers during the pre-announcement period is remarkably similar 
Table 1

Descriptive statistics

A. Characteristics of single and multiple bank-relationships

\begin{tabular}{|c|c|c|c|c|c|c|c|c|c|}
\hline & \multicolumn{3}{|c|}{ All } & \multicolumn{3}{|c|}{ Treatment } & \multicolumn{3}{|c|}{ Control } \\
\hline & Mean & Median & SD & Mean & Median & SD & Mean & Median & SD \\
\hline & \multicolumn{3}{|c|}{$\mathrm{n}=8,522$} & \multicolumn{3}{|c|}{$\begin{array}{c}\text { All borrowers } \\
\mathrm{n}=1,791\end{array}$} & \multicolumn{3}{|c|}{$\mathrm{n}=6,731$} \\
\hline Loan amount & 130,534 & 151,450 & 83,864 & 113,167 & 133,000 & 67,129 & 135,155 & 161,300 & 87,204 \\
\hline Total debt & 214,305 & 216,700 & 25,743 & 179,517 & 179,700 & 21,550 & 223,562 & 222,500 & 17,543 \\
\hline Collateral & 0.63 & 1.00 & 0.48 & 0.66 & 1.00 & 0.47 & 0.62 & 1.00 & 0.49 \\
\hline Single relationship & 0.25 & 0.00 & 0.43 & 0.22 & 0.00 & 0.42 & 0.25 & 0.00 & 0.43 \\
\hline Number of lenders & 2.28 & 2.00 & 1.21 & 2.24 & 2.00 & 1.20 & 2.29 & 2.00 & 1.21 \\
\hline Credit rating & 1.08 & 1.00 & 0.29 & 1.09 & 1.00 & 0.30 & 1.08 & 1.00 & 0.29 \\
\hline Size & 3.42 & 3.00 & 1.88 & 3.19 & 3.00 & 1.84 & 3.49 & 3.00 & 1.88 \\
\hline \multirow[t]{3}{*}{ Urban } & 0.40 & 0.00 & 0.49 & 0.31 & 0.00 & 0.46 & 0.42 & 0.00 & 0.49 \\
\hline & \multirow{2}{*}{\multicolumn{6}{|c|}{$\begin{array}{l}\text { Single relationship borrowers } \\
\qquad \mathrm{n}=402\end{array}$}} & \multirow{2}{*}{\multicolumn{3}{|c|}{$\mathrm{n}=1,701$}} \\
\hline & & & & & & & & & \\
\hline Loan amount & 211,759 & 213,000 & 24,137 & 176,147 & 177,600 & 16,903 & 220,175 & 219,350 & 16,798 \\
\hline Total debt & 211,759 & 213,000 & 24,137 & 176,147 & 177,600 & 16,903 & 220,175 & 219,350 & 16,798 \\
\hline Collateral & 0.73 & 1.00 & 0.45 & 0.69 & 1.00 & 0.46 & 0.74 & 1.00 & 0.44 \\
\hline Single relationship & 1.00 & 1.00 & 0.00 & 1.00 & 1.00 & 0.00 & 1.00 & 1.00 & 0.00 \\
\hline Number of lenders & 1.00 & 1.00 & 0.00 & 1.00 & 1.00 & 0.00 & 1.00 & 1.00 & 0.00 \\
\hline Credit rating & 1.09 & 1.00 & 0.30 & 1.08 & 1.00 & 0.28 & 1.09 & 1.00 & 0.30 \\
\hline Size & 3.71 & 4.00 & 1.85 & 3.67 & 4.00 & 1.83 & 3.72 & 4.00 & 1.86 \\
\hline \multirow[t]{3}{*}{ Urban } & 0.46 & 0.00 & 0.50 & 0.38 & 0.00 & 0.49 & 0.48 & 0.00 & 0.50 \\
\hline & \multicolumn{9}{|c|}{ Multiple relationship borrowers } \\
\hline & \multicolumn{3}{|c|}{$\mathrm{n}=6,419$} & \multicolumn{3}{|c|}{$\mathrm{n}=1,389$} & \multicolumn{3}{|c|}{$\mathrm{n}=5,030$} \\
\hline Loan amount & 103,923 & 97,700 & 79,226 & 94,940 & 97,100 & 65,174 & 106,404 & 97,950 & 82,521 \\
\hline Total debt & 215,139 & 218,000 & 26,195 & 180,492 & 181,100 & 22,630 & 224,707 & 223,850 & 17,643 \\
\hline Collateral & 0.60 & 1.00 & 0.49 & 0.65 & 1.00 & 0.48 & 0.58 & 1.00 & 0.49 \\
\hline Single relationship & 0.00 & 0.00 & 0.00 & 0.00 & 0.00 & 0.00 & 0.00 & 0.00 & 0.00 \\
\hline Number of lenders & 2.70 & 2.00 & 1.11 & 2.59 & 2.00 & 1.13 & 2.73 & 2.00 & 1.10 \\
\hline Credit rating & 1.08 & 1.00 & 0.29 & 1.09 & 1.00 & 0.31 & 1.08 & 1.00 & 0.29 \\
\hline Size & 3.33 & 3.00 & 1.88 & 3.05 & 3.00 & 1.82 & 3.41 & 3.00 & 1.88 \\
\hline Urban & 0.38 & 0.00 & 0.48 & 0.30 & 0.00 & 0.46 & 0.40 & 0.00 & 0.49 \\
\hline
\end{tabular}

across 23 industries, 6 size categories, and 24 states for both exclusive and multiple-relationship borrowers. We cannot reject the null that the distributions of treatment and control borrowers are equal in Kolmogorov-Smirnov tests for either the exclusive or multiple relationship sample.

In Figure 2 there appears to be more borrowers with debt just above the $\$ 200,000$ threshold than just below in February 1998. This may indicate that borrowers try to obtain at least $\$ 200,000$ of total debt to have visible credit ratings. Importantly, however, any ability to manipulate does not appear to be precise, as some salient average characteristics of the borrowers in February 1998 appear remarkably continuous above and below the threshold, suggesting that any manipulation does not lead to uncomparability of the treatment and control samples. ${ }^{10}$

10 Cross-sectional differences are similar in January and in March 1998. 
The Review of Financial Studies / v 0 n 02017

Table 1

Continued

B. Bank relationships across sample periods

\begin{tabular}{|c|c|c|c|c|}
\hline \multirow{3}{*}{ Period $=$} & \multicolumn{4}{|c|}{ Sample means } \\
\hline & All & Pre & Interim & Post \\
\hline & \multicolumn{4}{|c|}{$\begin{array}{c}\text { All borrowers } \\
\mathrm{n}=46,891\end{array}$} \\
\hline Loan amount & 126,521 & 130,534 & 129,646 & 124,540 \\
\hline Total debt & 221,312 & 214,305 & 221,520 & 223,234 \\
\hline Collateral & 0.65 & 0.63 & 0.64 & 0.65 \\
\hline Single relationship & 0.24 & 0.30 & 0.25 & 0.22 \\
\hline Number of lenders & 2.61 & 2.28 & 2.58 & 2.72 \\
\hline Credit rating & 1.24 & 1.08 & 1.17 & 1.30 \\
\hline Size & 3.41 & 3.42 & 3.42 & 3.40 \\
\hline \multirow[t]{2}{*}{ Urban } & 0.38 & 0.40 & 0.40 & 0.38 \\
\hline & \multicolumn{4}{|c|}{$\begin{array}{l}\text { Single relationship borrowers } \\
\qquad \mathrm{n}=11,698\end{array}$} \\
\hline Loan amount & 198,213 & 211,759 & 206,249 & 192,235 \\
\hline Total debt & 221,834 & 211,759 & 212,983 & 227,066 \\
\hline Collateral & 0.75 & 0.73 & 0.74 & 0.75 \\
\hline Single relationship & 0.83 & 1.00 & 0.91 & 0.76 \\
\hline Number of lenders & 1.23 & 1.00 & 1.13 & 1.33 \\
\hline Credit rating & 1.32 & 1.09 & 1.19 & 1.42 \\
\hline Size & 3.71 & 3.71 & 3.71 & 3.71 \\
\hline \multirow[t]{2}{*}{ Urban } & 0.44 & 0.46 & 0.46 & 0.43 \\
\hline & \multicolumn{4}{|c|}{$\begin{array}{l}\text { Multiple relationship borrowers } \\
\qquad \mathrm{n}=35,193\end{array}$} \\
\hline Loan amount & 102,691 & 103,923 & 103,883 & 102,020 \\
\hline Total debt & 221,138 & 215,139 & 224,391 & 221,959 \\
\hline Collateral & 0.61 & 0.60 & 0.61 & 0.62 \\
\hline Single relationship & 0.04 & 0.07 & 0.02 & 0.04 \\
\hline Number of lenders & 3.07 & 2.70 & 3.07 & 3.18 \\
\hline Credit rating & 1.21 & 1.08 & 1.16 & 1.26 \\
\hline Size & 3.31 & 3.33 & 3.32 & 3.29 \\
\hline Urban & 0.37 & 0.38 & 0.37 & 0.36 \\
\hline
\end{tabular}

This table presents descriptive statistics for the borrower-bank relationships across treatment and control borrowers during the pre-announcement period only (panel A), and for the pre, interim, and post- credit reform expansion periods (panel B). Treatment (control) borrowers are those with total debt between $\$ 150,000$ and $\$ 200,000$ (\$200,000 and \$250,000) during the pre-announcement period (January to March 1998). The registry expansion announcement (the interim period) covers April to June 1998, and the post-expansion period, when information has been made public, includes the twelve months from July 1998 onward. Panels A and B are divided in three panels following different samples: for all borrower-bank relationships; for single relationship borrowers; and for multiple relationship borrowers. Loan amount is the dollar loan for each borrower-bank relationship; total debt is the total dollar amount of loans for each borrower across all bank relationships; collateral is an indicator variable equal to one if the loan is secured with collateral; single relationship is an indicator variable equal to one if the borrower has just one bank relationship; number of lenders is the number of lenders the borrower has; credit ratings are assigned by each lender to a borrower, and are integer between one (best) and five (worst); size is an indicator variable equal to one if the borrower size classification is equal or greater than three $(>25$ employees); and, urban is an indicator variable equal to one if the borrower is located in the capital city of each state. A rating of one (two) represents a borrower in good standing with no (some) potential repayment problems, while a rating greater than two represents a degree of default according to specified criteria. 
Industry classification

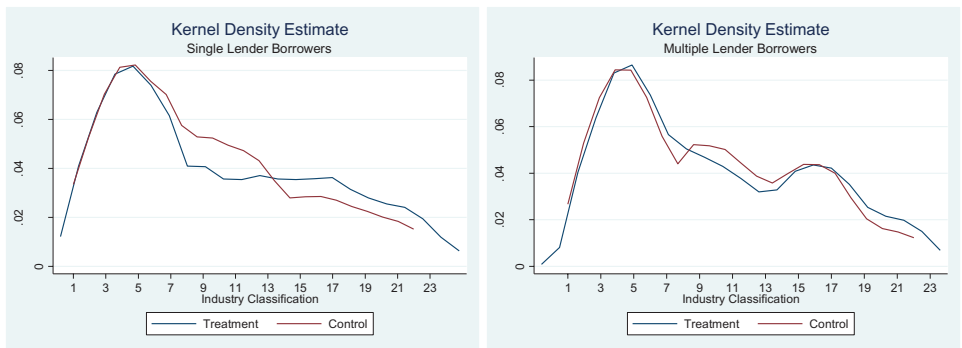

Size

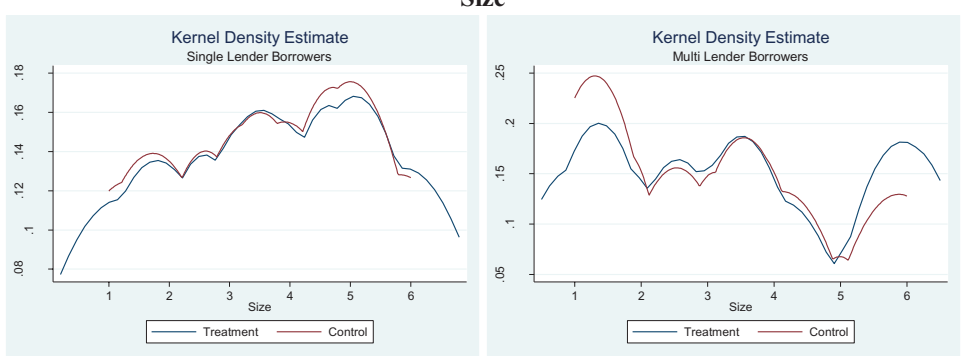

Geographical location (state)

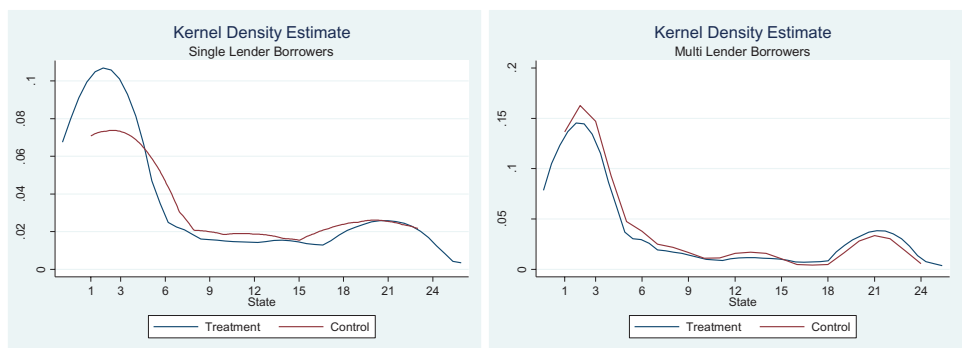

Figure 1

The distribution of treatment and control borrowers across observable characteristics before the credit reform expansion

These plots show the cross-sectional kernel density distributions for observable characteristics across treatment and control borrowers during the period before the credit registry reform announcement from January 1998 to March 1998 (pre-announcement period). The three time-invariant observable characteristics are industry classification, size, and geographical location. The plots are for all treatment and control borrowers in single lending relationships (left-hand side) and multiple lending relationships samples (right-hand side). Treatment (control) borrowers are those with total debt between $\$ 150,000$ and $\$ 200,000$ ( $\$ 200,000$ and $\$ 250,000$ ) during the period before the credit registry reform announcement from January 1998 to March 1998. Industry classification includes 23 unique industries following the Argentinean federal tax administration authority (Administración Federal de Ingresos Públicos (AFIP)). We use the classification according to the economic activities defined in Clasificación de Actividades Económicas (CLAE number 883). The size measure is a categorical variable from one (lowest) to six (highest) measured by the borrower's number of employees. The geographical location corresponds to one of the 24 states where the borrower is legally incorporated. The source of information for size and geographical location is the Argentinean federal tax administration authority (AFIP). We also perform two-sample Kolmogorov-Smirnov tests for the equality of distributions for each of the observable characteristics across treatment and control borrowers in the single lending relationships and the multiple lending relationships samples. We cannot reject the null that the distributions across treatment and control borrowers for each of the observable characteristic are not statistically different from each other: The test statistics ( $p$-value) are 0.0593 $(0.917)$ for industry; $0.0636(0.878)$ for size; $0.1146(0.199)$ for geography in the single-lender sample; and $0.0753(0.523), 0.080(0.251)$, and $0.0931(0.263)$ respectively in the multiple-lender sample. 


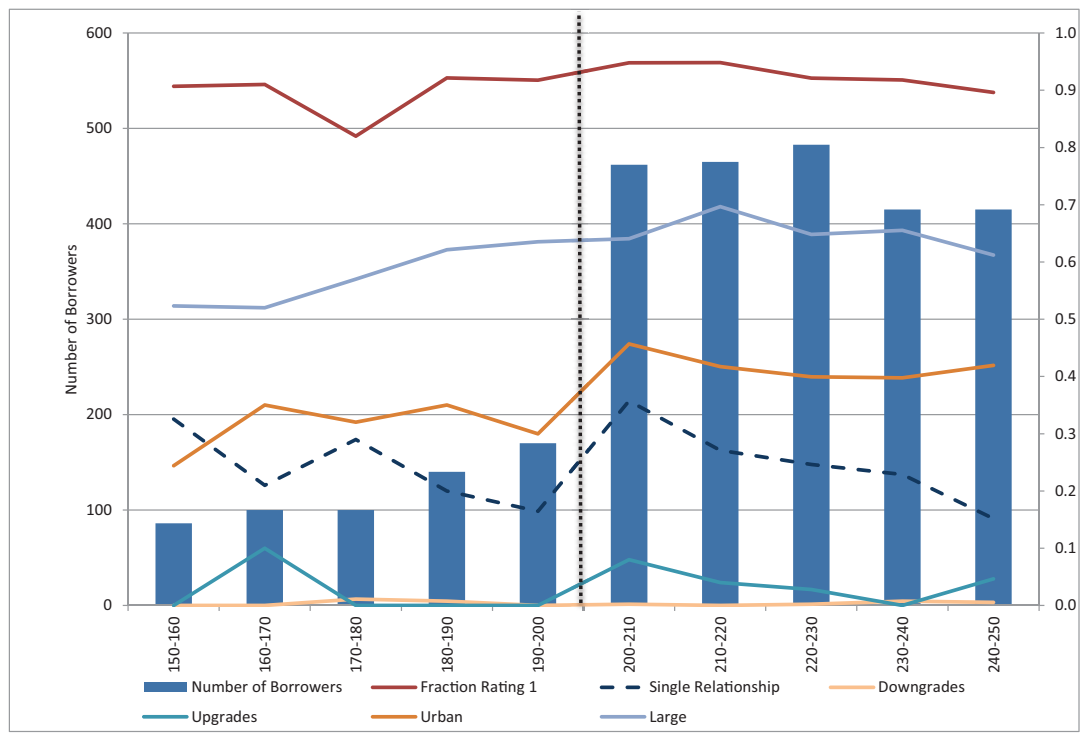

Figure 2

Distribution of borrowers by total debt before the credit reform expansion

This figure shows the cross-sectional distribution of the number of borrowers for different levels of total debt and some average salient observable characteristics of the borrowers in February 1998. The plot is for all the treatment and control borrowers in the sample. Treatment (control) borrowers are those with total debt between $\$ 150,000$ and $\$ 200,000$ ( $\$ 200,000$ and $\$ 250,000$ ) during the period before the credit registry reform announcement from January 1998 to March 1998. The left-hand-side axis plots the number of borrowers per $\$ 10 \mathrm{~K}$ bin. The right-hand side axis plots some average borrower characteristics also per $\$ 10 \mathrm{~K}$ bin including the fractions of borrowers with (1) rating $=1$; (2) single lending relationship; (3) downgrades; (4) upgrades; (5) urban, and (6) large = size is equal or greater to three ( $>25$ employees). Urban and large are indicator variables equal to one if the borrower is located in the capital city of each state, and the borrower size is equal or greater than three, respectively.

This evidence provides strong support for our identifying assumption that the treatment and control borrowers are similar once we subordinate to their ratings and to their single or multiple relationship borrower status. ${ }^{11}$

In panel B of Table 1, we provide descriptive statistics on bank-relationships in the pre-announcement, interim, and post-reform periods. A few striking observations relate to our study. First, borrowers' credit ratings worsen, on average, subsequent to the credit registry's expansion. However, the credit ratings of multiple borrowers worsen by less than for borrowers with exclusive lenders, with a decrease in the rating of 0.18 for multiple relationship borrowers in comparison to 0.33 for borrowers with an exclusive lender.

Second, while exclusive relationships become less common post-reform, the average number of banks increases less for borrowers with an exclusive relationship than for borrowers with multiple relationships, consistent with

11 Further supporting our identifying assumption, Table IA.3 of the Internet Appendix shows that borrowers become more likely to default in the post-period. However, there is also no difference in defaults for the treatment or the control borrowers in the single- or multiple-lender sample. 
exclusive lenders protecting their informational rents. Third, exclusive relationship borrowers exhibit the largest increase in total debt even though the overall increase in borrowing was modest following the reform.

Figure 3 further explores how credit ratings vary around the registry reform. Distinguishing between the single-lender subsample (Figure 3A) and the multiple-lender subsample (Figure 3B), we plot the proportion of borrowers that have a credit rating of two. We only focus on borrowers not in default, in order to capture the discretionary nature of the rating process, and track borrowers in the three-month pre-announcement period, the three-month interim period, and the three-month post-reform period. In Figure 3A, the treatment borrowers with exclusive lending relationships exhibit significant downgrades in the interim period: $3.5 \%$ of the treatment borrowers are downgraded compared with only one-quarter of a percentage of the control borrowers. The differencein-differences estimate of $3.3 \%$ is economically and statistically significant (at the $10 \%$ level). In the post-reform period, approximately $1 \%$ of the exclusive lender treatment group is downgraded, but the difference is not significant in either absolute or in relative terms.

Interestingly, the treatment group converges to the control group. This is precisely what we would expect based on our hypothesis because the ratings of borrowers in the control group were already public. Therefore, if the mechanisms we highlight are at work, banks already should have strategically downgraded some of the borrowers above the threshold.

In Figure 3B, we focus on the borrowers with multiple relationships. The borrowers in the treatment group exhibit significant upgrades in the interim period: $2.9 \%$ of these borrowers are upgraded, while $0.1 \%$ of the borrowers in the control group are downgraded. The difference-in-differences of 3.0\% is economically and statistically significant (at the $5 \%$ level). There is no evidence of significant upgrade or downgrade activity in the post-reform period. Also in this case, the proportion of borrowers in the treatment group with a rating of two appears to converge to the proportion of borrowers with a rating of two in the control sample.

Figure 4 reproduces Figure 3, but considers only local banks. The patterns that emerge are very similar to Figure 3 indicating that the differences before and after the reform are not driven by an increasing presence of foreign banks, or by local banks becoming more similar to foreign banks.

In the Internet Appendix, we present analogous figures for large domestic banks (Figure IA.2) and foreign banks (Figure IA.3). As we will discuss in Subsection 5.1, the tendency to strategically downgrade is driven by local banks, while all banks appear inclined to strategically upgrade multiple-lender borrowers.

This evidence is fully consistent with the conjecture that banks manipulate ratings downward to capture good borrowers, and manipulate ratings upward to pre-empt runs on riskier borrowers. Since lenders strategically downgrade some borrowers and strategically upgrade others, the manipulation does not 

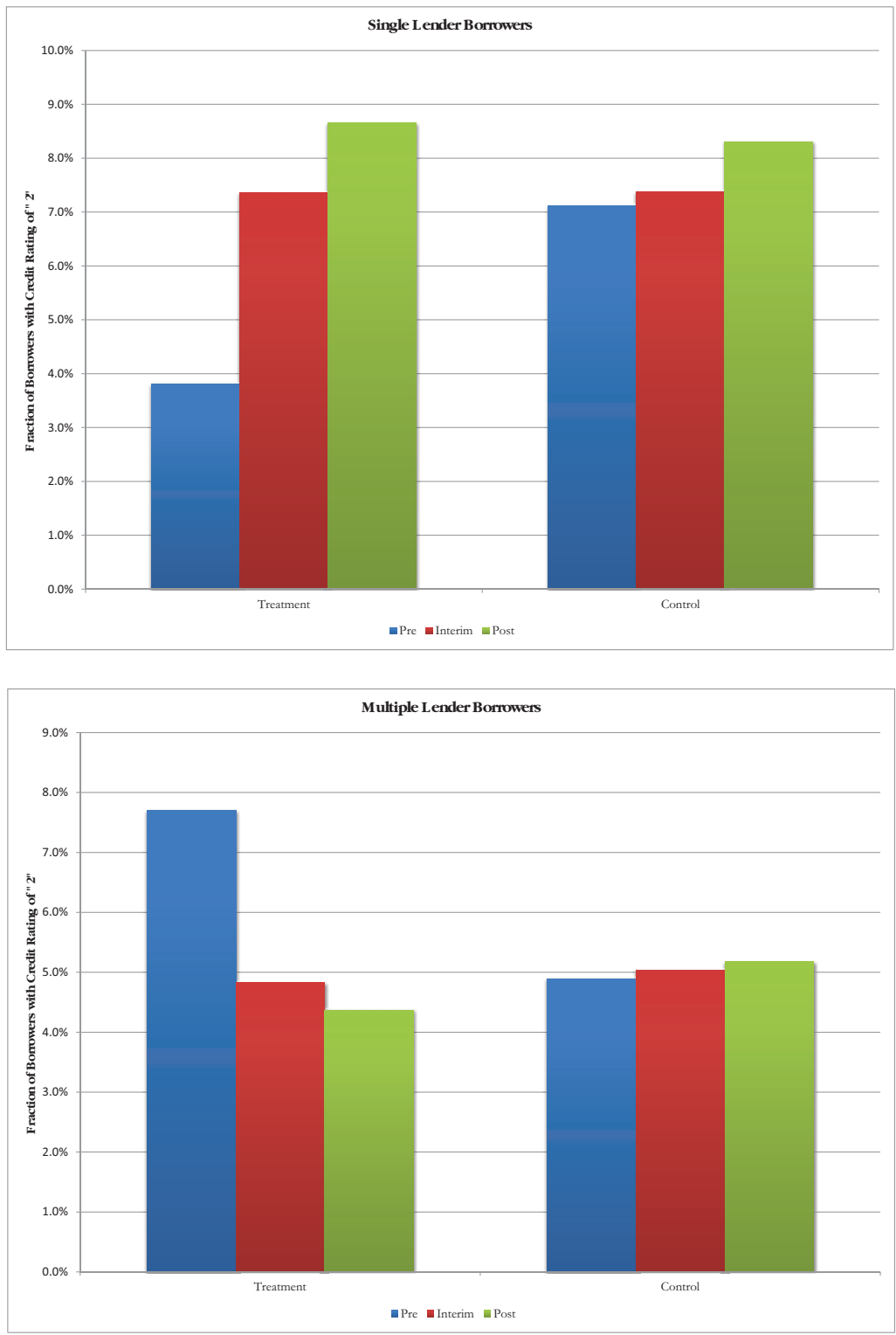

Figure 3

Upgrades and downgrades around the credit reform expansion

These plots show the fraction of borrowers with a Rating $=2$ for single lending relationship borrowers and multiple lending relationship borrowers, respectively. Statistics are shown for three months prior to the credit registry expansion announcement (pre-announcement period), during a period in which the credit registry expansion has been announced, but information about the borrowers has not yet been made public (interim period), and after information about the borrowers has been made public (post-expansion period). We track the bank-borrower relationships that existed as of January 1998 for borrowers that did not become delinquent or default in the pre-, interim, and three-month post-reform period. The unit of observation is at the borrower-bank-month level. 

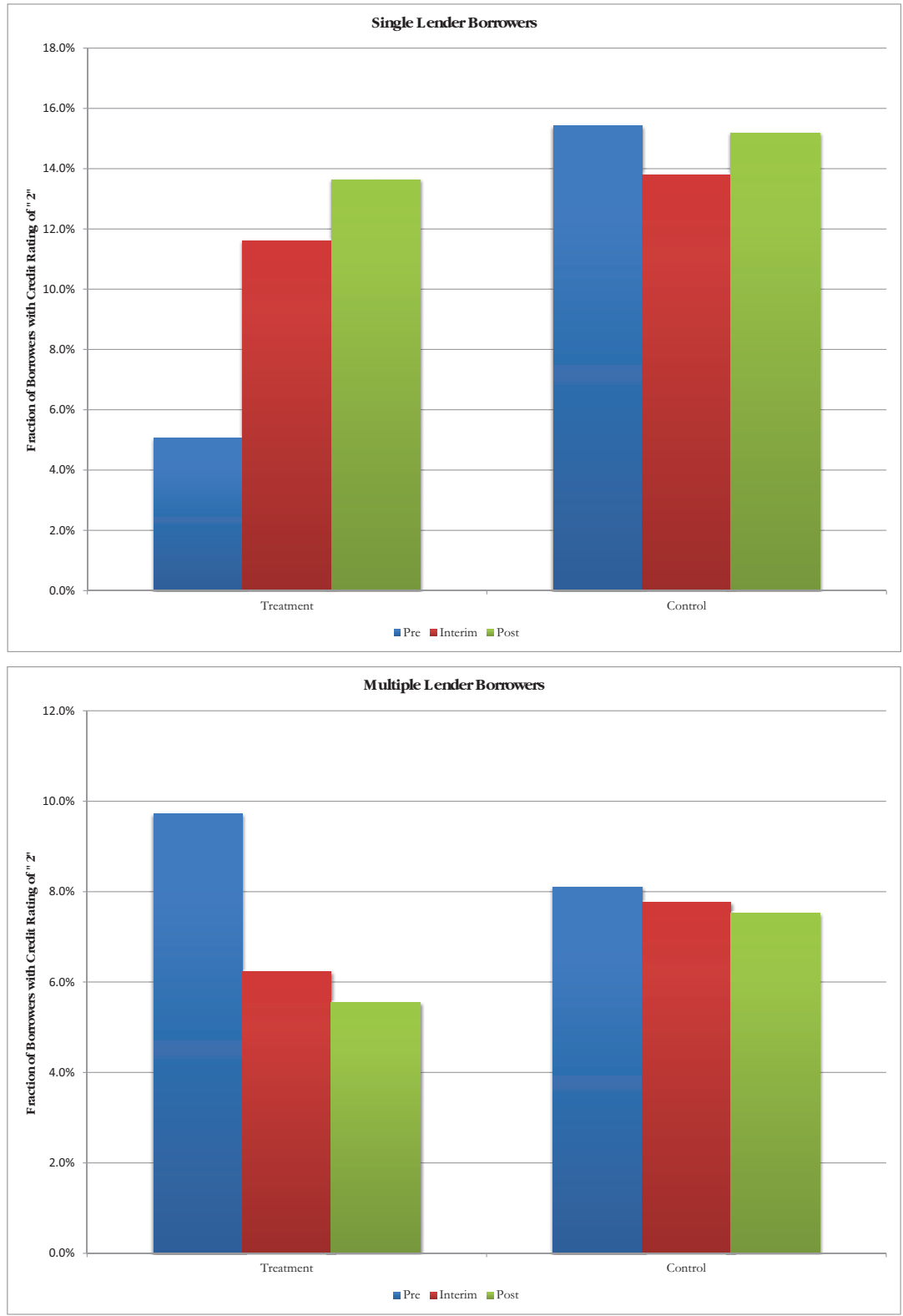

Figure 4

Upgrades and downgrades around the credit reform expansion: Local banks

These plots show the fraction of borrowers with a Rating $=2$ for single lending relationship borrowers and multiple lending relationship borrowers, respectively, considering lending relationships with local banks only. Statistics are shown for three months prior to the credit registry expansion announcement (pre-announcement period), during a period in which the credit registry expansion has been announced, but information about the borrowers has not yet been made public (interim period), and after information about the borrowers has been made public (post-reform period). We track the bank-borrower relationships that existed as of January 1998 for borrowers that did not become delinquent or default in the pre-, interim, and three-month post-reform period. The unit of observation is at the borrower-bank-month level. 
give rise to systematic rating inflation or deflation and may therefore not to be easily detected by regulators.

Figures 3 and 4 also show that borrowers in the treatment group with an exclusive relationship appear healthier than borrowers with multiple relationships in the treatment group in the pre-announcement period. The separation on risk is consistent with adverse selection models of credit rationing (Stiglitz and Weiss 1981). Banks that are unable to evaluate borrowers offer a loan contract that is acceptable only to riskier borrowers, while healthier borrowers contract exclusively to overcome information asymmetry.

\section{Results}

\subsection{Strategic downgrades of high-quality borrowers}

Table 2 provides evidence that treated high-quality borrowers, defined as borrowers that maintain a rating of one and total loans below the $\$ 200,000$ threshold in the period preceding the announcement of the credit registry expansion, are more likely to be downgraded in the interim period than borrowers in the control sample. ${ }^{12}$ We consider only the subsample of borrowers that in the pre-announcement period entertained a single relationship, for which we expect banks' informational rent, and, consequently, incentives to manipulate ratings before their release, to be stronger.

In Column 1, treated borrowers with a rating of one appear 2.6 percentage points more likely to be downgraded during the interim period than borrowers in the control sample. This is economically large relative to the unconditional probability of a downgrade of 0.016 in the whole sample and 0.011 in the pre-announcement period.

Under the identification assumption that borrowers in the treatment group did not receive stronger negative shocks than borrowers with slightly larger loans included in the control sample, this evidence indicates that banks strategically downgrade high-quality borrowers to preserve their informational advantage.

In Column 2, we test whether the propensity to downgrade high-quality borrowers persist in the post-reform period, once the ratings have been made public. A higher propensity to downgrade borrowers in the treatment group than borrowers in the control group may suggest that the quality of treated borrowers is deteriorating, possibly because of the approaching Argentinian recession, and should be interpreted as evidence against our identification assumption that the treatment group and the control group borrowers are similarly exposed to shocks. We find no evidence that banks continue to abnormally downgrade the treatment group borrowers in the post-reform period.

To provide further evidence that borrowers above and below the threshold are not subject to asymmetric shocks, Figure 5 shows the dynamic effects

12 Once a borrower has been downgraded, we exclude it from the sample, which is why the number of observations in Table 2 is lower than that in Table 1. 
Table 2

Strategic downgrades of high-quality borrowers

Dependent variable

Downgrades from 1 to 2

Sample lender

Period

\begin{tabular}{lr} 
Single \\
\hline All & 3-month post
\end{tabular}

\begin{tabular}{lcccccc}
\cline { 3 - 5 } \cline { 5 - 6 } & $(1)$ & $(2)$ & $(3)$ & $(4)$ & $(5)$ & $(6)$ \\
\hline Treated & 0.004 & -0.006 & 0.002 & 0.008 & 0.000 & 0.004 \\
& $(0.004)$ & $(0.007)$ & $(0.004)$ & $(0.007)$ & $(0.004)$ & $(0.005)$
\end{tabular}

Treated $\times$ Interim

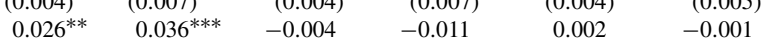

Treated $\times$ Post

$\begin{array}{llll}(0.012) & (0.014) \quad(0.009) & (0.011)\end{array}$

$(0.009) \quad(0.009)$

Treated $\times$ Interim $\times$ Local

$0.013-0.008$

$\begin{array}{cc}0.013 & -0.008 \\ (0.008) & (0.008)\end{array}$

$(0.008)$

Treated $\times$ Post $\times$ Local

$\begin{array}{llll}0.053^{* *} & 0.064^{* * *} & 0.038^{*} & 0.054^{* *} \\ (0.021) & (0.023) & (0.020) & (0.021)\end{array}$

Bank controls

Borrower controls

Time fixed effects

Bank fixed effects

Industry fixed effects

Bank-time fixed effects

Industry-time fixed effects

$\begin{array}{lcccccc}\text { No. observations } & 9,558 & 9,558 & 9,558 & 9,558 & 9,558 & 5,151 \\ \text { R-sq. } & 0.03 & 0.03 & 0.03 & 0.03 & 0.16 & 0.18\end{array}$

$0.053^{*}$
$(0.021)$

0.034

$(0.020) \quad(0.021)$

$\begin{array}{lcccccc}\text { No. observations } & 9,558 & 9,558 & 9,558 & 9,558 & 9,558 & 5,151 \\ \text { R-sq. } & 0.03 & 0.03 & 0.03 & 0.03 & 0.16 & 0.18\end{array}$

Yes $\quad$ Yes $\quad$ Yes $\quad$ Yes

Yes

Yes No

No No

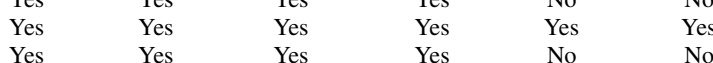

Yes Yes $\quad$ Yes $\quad$ Yes N No

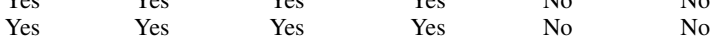

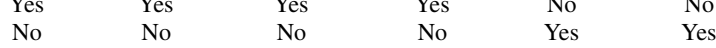

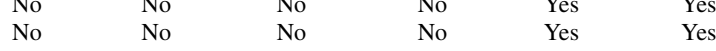

This table presents the difference-in-differences effect of the credit registry expansion announcement (interim period) and public information (post-expansion period) on downgrade hazard rates, estimated using OLS. Treatment (control) borrowers are those with total debt between $\$ 150,000$ and $\$ 200,000$ ( $\$ 200,000$ and $\$ 250,000$ ) during the pre-announcement period (January to March 1998). The dependent variable, downgrade, is from rating $=1$ to rating $=2$. The sample is all treatment and control borrowers with a rating $=1$ in the pre-announcement period, and with a single lending relationship in the pre-announcement period. Columns (1) to (5) use a 12-month post-period horizon, while Column (6) uses a three-month post-period horizon. We exclude borrowers that have been downgraded from the sample, explaining why the number of observations is lower than in Table 1. Local is an indicator variable equal to one if the lender is a local bank. The unit of observation is at the borrower-bankmonth level. Bank controls include $\log$ (total assets), return on assets, capitalization (\%), $\log$ (number of branches), nonperforming loans-to-total assets, deposits-to-total assets, and growth on total assets, while borrower controls include the $\log (\mathrm{debt})$, state, size, industry classification, and urban. Standard errors are clustered at the borrower level. *,**, and *** indicate statistical significance at the $10 \%, 5 \%$, and $1 \%$ level.

of downgrades. It plots the coefficient estimate, obtained including the same controls as in Column 1, of the banks' propensity to downgrade treated borrowers in each month. The propensity of high-quality borrowers with single lenders to be downgraded is remarkably similar in the pre- and post-reform periods. All differences are concentrated in the interim period as our hypothesis would predict.

Local banks are known to have a stronger informational advantage than other lenders, often under the form of soft information, which is difficult to collect in large banks that are active nation-wide and internationally (Berger et al. 2005). Therefore, we expect local banks to have more to lose in terms of informational rents from sharing the private information contained in the credit rating. Consistent with our hypothesis that banks' abnormal propensity to downgrade in the interim period is driven by the desire to protect their informational rents, Columns 3 and 4 show that the tendency to downgrade 


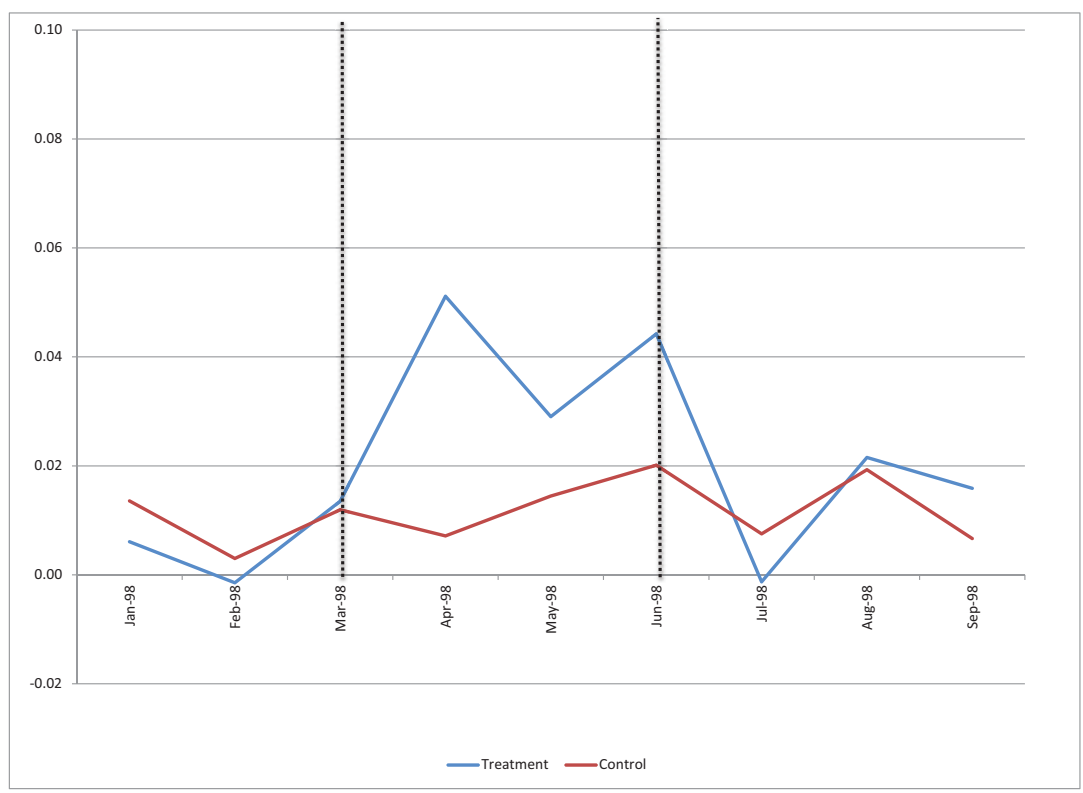

\section{Figure 5}

Conditional estimates of strategic downgrades by month for single lenders
This figure reports single relationship lenders' propensity to downgrade high-quality borrowers by month. The parameter estimates reported are for the coefficient of the interaction between the Treated ${ }_{i}$ dummy and monthly dummies for each month from January 1998 to September 1998. The parameter estimates are obtained by controlling for the Treated ${ }_{i}$ dummy, each of the monthly dummies, the bank and borrower controls, as well as bank fixed effects. Bank controls include log(total assets), return on assets, capitalization (\%), log(number of branches), nonperforming loans-to-total assets, deposits-to-total assets, and growth on total assets, while borrower controls include the $\log (\mathrm{debt})$, state, size, industry classification, and urban.

high-quality single-lender borrowers is entirely due to local banks. Column 4 also shows that this tendency emerges in the interim, but not in the post-reform period, indicating that the customers of local banks are unlikely to be more exposed to shocks than borrowers in the control group.

In Column 5, we control for bank-specific shocks and industry specificshocks by including bank-time and industry-time fixed effects. The results are invariant. The robustness of the results indicates that bank-specific shocks and borrower industry composition or seasonal effects cannot drive our findings. ${ }^{13}$ Finally, Column 6 shows that our results are unaffected when we use a three month post-reform period, instead of a nine month one as in the earlier specifications.

While we expect banks to have higher informational rents on borrowers with which they entertain exclusive relations, lenders to borrowers with multiple relationships may also have private information because borrowers

13 Table IA.4 in the Internet Appendix further controls for the possibility that treated borrowers are more likely to be in agriculture and relatively more exposed to shocks in the interim period. The triple interaction term Treated $x$ Agriculture $\times$ Interim is not statistically significant dispelling this concern. 
Table 3

Cross-sectional lender differences in incentives to strategically downgrade

\begin{tabular}{|c|c|c|c|c|}
\hline \multirow{3}{*}{$\begin{array}{l}\text { Dependent variable } \\
\text { Sample lender }\end{array}$} & \multicolumn{4}{|c|}{ Downgrades from 1 to 2} \\
\hline & \multicolumn{4}{|c|}{ All } \\
\hline & (1) & (2) & (3) & (4) \\
\hline Treated & $\begin{array}{c}-0.000 \\
(0.002)\end{array}$ & $\begin{array}{c}0.001 \\
(0.003)\end{array}$ & $\begin{array}{r}-0.000 \\
(0.003)\end{array}$ & $\begin{array}{c}0.003 \\
(0.004)\end{array}$ \\
\hline Treated $\times$ Interim & $\begin{array}{l}0.015^{* * *} \\
(0.005)\end{array}$ & $\begin{array}{c}0.001 \\
(0.006)\end{array}$ & $\begin{array}{l}0.003 \\
(0.007)\end{array}$ & $\begin{array}{c}0.016 \\
(0.011)\end{array}$ \\
\hline Treated $\times$ Interim $\times$ Local & & $\begin{array}{l}0.026^{* *} \\
(0.011)\end{array}$ & $\begin{array}{l}0.040^{* * *} \\
(0.015)\end{array}$ & $\begin{array}{l}0.022^{* *} \\
(0.011)\end{array}$ \\
\hline Treated $\times$ Post & & & $\begin{array}{l}0.002 \\
(0.004)\end{array}$ & \\
\hline Treated $\times$ Post $\times$ Local & & & $\begin{array}{l}0.015 \\
(0.010)\end{array}$ & \\
\hline $\log (\#$ banks $)$ & & & & $\begin{array}{c}-0.002 \\
(0.002)\end{array}$ \\
\hline Treated $\times$ Interim $\times \log (\#$ banks $)$ & & & & $\begin{array}{c}-0.016^{*} \\
(0.009)\end{array}$ \\
\hline Borrower controls & Yes & Yes & Yes & Yes \\
\hline Bank-time fixed effects & Yes & Yes & Yes & Yes \\
\hline Industry-time fixed effects & Yes & Yes & Yes & Yes \\
\hline No. observations & 35,269 & 35,269 & 35,269 & 35,269 \\
\hline R-sq. & 0.08 & 0.08 & 0.08 & 0.08 \\
\hline
\end{tabular}

This table presents the difference-in-differences effect of the registry expansion announcement (interim period) and public information (post-expansion period) on downgrade hazard rates by bank-type, estimated using OLS. Treatment (control) borrowers are those with total debt between $\$ 150,000$ and $\$ 200,000$ ( $\$ 200,000$ and $\$ 250,000$ ) during the pre-announcement period (January to March 1998). The dependent variable, downgrade, is from rating $=1$ to rating $=2$. The sample is all treatment and control borrowers with a single and multiple lending relationships and with a rating of one in the pre-announcement period. The unit of observation is at the borrower-bank-month level. Local is an indicator variable equal to one if the lender is a local bank; log (\#banks) is the log of the total number of bank-borrower relationships. We omit from reporting the coefficient estimates of Treated $\times$ Local in Columns (2), (3), and (4). Borrower controls include $\log (\mathrm{debt})$, state, size, industry classification, and urban. Standard errors are clustered at the borrower level. *,**, and *** indicate statistical significance at the $10 \%$, $5 \%$, and $1 \%$ level.

may entertain transactional relationships with some of their multiple banks and have a close relationship with a few others.

Table 3 shows that all our findings hold also for borrowers with multiple relationships. That is, we find an abnormal propensity to downgrade highquality borrowers in the interim period (Column 1), which is driven by local banks (Column 2) and does not emerge in the post-reform period once the rating becomes public (Column 3). As we would expect, the effects are somewhat smaller than in the case in which we focus on single relationship borrowers.

In Column 4, we explicitly test the conjecture that the incentives to strategically downgrade borrowers with multiple relationships are weaker. This conjecture is confirmed by the fact that the triple interaction term between Treated $_{i} \times$ Interim $_{t} \times \log (\#$ Banks $)$ is negative and significant.

These results support our conjecture that banks strategically downgrade highquality borrowers below the threshold to preserve their informational rents. In particular, any alternative explanation based on borrowers below the threshold being more exposed to shocks would have to explain why borrowers below the threshold with multiple banks are less likely to be downgraded. 
Table IA.5 in the Internet Appendix further evaluates the merit of the criticism that borrowers below the threshold are more exposed to negative shocks. If a negative shock indeed explained our findings, we would expect to see downgrades also to ratings that have less scope for manipulation, such as downgrades from 1 to 3,4 , and 5 . We find no evidence of this both in the singlelender sample (Column 1) or in the sample that also includes multiple-lender borrowers (Column 2).

The rest of Table IA.5 presents a local sample analysis that further supports our identifying assumptions. While in our benchmark specifications we consider borrowers with total debt between $\$ 150,000$ and $\$ 250,000$, in Columns 3 and 4 we reestimate the specification in Column 5 of Table 2 and restrict the interval to borrowers with total debt between $\$ 175,000$ and $\$ 225,000$ and between $\$ 125,000$ and $\$ 275,000$, respectively. It is comforting that the estimates are hardly affected when we vary the extent of unobserved heterogeneity by changing the sample interval. Also, the effect of Treated $\times$ Interim $_{t}$ is not statistically significant in the placebo tests presented in Columns 5 and 6 , where borrowers with loan amounts strictly below and strictly above the cutoff are considered in the estimation.

Table 4 tests whether more opaque borrowers are more likely to be downgraded. If banks' strategic downgrades aim to preserve informational rents, banks should downgrade to a lower extent borrowers with less information asymmetry. Large borrowers are more visible and therefore less informationally captured. Columns 1 and 2 of Table 4 show that indeed strategic downgrades affect large borrowers, defined as firms with employees above the median of 25 , to a lesser extent. Urban borrowers may also be more visible to loan officers. To the extent that they face less asymmetric information, their lenders are able to enjoy less informational rents and should have weaker incentives to downgrade them, as we find in Columns 3 and 4 of Table 4.

In Columns 5 and 6 of Table 4, we further show that borrowers in areas in which lenders face less competition are less likely to be downgraded. We measure lack of competition as the number of borrowers per branch in a state. In states with a higher number of borrowers per branch, competition is lower and borrowers are less likely to be poached even after the expansion of the credit registry. Incentives to strategically downgrade should therefore be weaker, as we find.

The manipulation of credit ratings implies that the pool of borrowers with a rating of two becomes less likely to default as some high-quality borrowers have been downgraded. This is precisely what we find in panel A of Table 5. Treatment group borrowers with a credit rating of two in the period preceding the announcement of the credit registry expansion are more likely to default in the following 6 or 12 months than treatment-group borrowers receiving the same rating in the interim or the post-reform period, relative to the control group. Thus, on average, borrowers with a rating of two are better quality after the announcement of the credit registry expansion than 
Table 4

Cross-sectional borrower differences in incentives to strategically downgrade

Dependent variable

Downgrades from 1 to 2

Sample lenders

Characteristic

Downgrades fro
Single

\begin{tabular}{|c|c|c|c|c|c|c|}
\hline \multirow[t]{2}{*}{ Characteristic } & \multicolumn{2}{|c|}{ Large borrower } & \multicolumn{2}{|c|}{ Urban borrower } & \multicolumn{2}{|c|}{ Low competition } \\
\hline & (1) & (2) & (3) & (4) & (5) & (6) \\
\hline Treated & $\begin{array}{l}-0.010 \\
(0.007)\end{array}$ & $\begin{array}{r}-0.009 \\
(0.006)\end{array}$ & $\begin{array}{c}0.002 \\
(0.006)\end{array}$ & $\begin{array}{r}-0.008 \\
(0.006)\end{array}$ & $\begin{array}{c}0.003 \\
(0.004)\end{array}$ & $\begin{aligned}-0.000 \\
(0.004)\end{aligned}$ \\
\hline Treated $\times$ Interim & $\begin{array}{l}0.058^{* *} \\
(0.024)\end{array}$ & $\begin{array}{c}-0.001 \\
(0.012)\end{array}$ & $\begin{array}{l}0.043^{* *} \\
(0.018)\end{array}$ & $\begin{array}{c}0.001 \\
(0.011)\end{array}$ & $\begin{array}{l}0.026^{* *} \\
(0.012)\end{array}$ & $\begin{array}{c}0.004 \\
(0.009)\end{array}$ \\
\hline Treated $\times$ Interim $\times$ Characteristic & $\begin{array}{c}-0.048^{*} \\
(0.028)\end{array}$ & $\begin{array}{c}0.003 \\
(0.013)\end{array}$ & $\begin{array}{l}-0.047^{* *} \\
(0.021)\end{array}$ & $\begin{array}{c}0.000 \\
(0.017)\end{array}$ & $\begin{array}{c}-0.030^{*} \\
(0.016)\end{array}$ & $\begin{array}{r}-0.029^{*} \\
(0.016)\end{array}$ \\
\hline Treated $\times$ Interim $\times$ Local & & $\begin{array}{l}0.077^{* *} \\
(0.032)\end{array}$ & & $\begin{array}{l}0.056^{* *} \\
(0.026)\end{array}$ & & $\begin{array}{r}0.035^{*} \\
(0.020)\end{array}$ \\
\hline $\begin{array}{l}\text { Treated } \times \text { Interim } \times \text { Characteristic } \\
\quad \times \text { Local }\end{array}$ & & $\begin{array}{r}-0.066^{*} \\
(0.041)\end{array}$ & & $\begin{array}{c}-0.070^{*} \\
(0.037)\end{array}$ & & \\
\hline Borrower controls & Yes & Yes & Yes & Yes & Yes & Yes \\
\hline Bank-time fixed effects & No & Yes & Yes & Yes & Yes & Yes \\
\hline Industry-time fixed effects & No & Yes & Yes & Yes & Yes & Yes \\
\hline No. observations & 9,558 & 9,558 & 9,558 & 9,558 & 9,558 & 9,558 \\
\hline R-sq. & 0.16 & 0.16 & 0.16 & 0.16 & 0.16 & 0.16 \\
\hline
\end{tabular}

This table presents the difference-in-differences effect of the registry expansion announcement (interim period) on downgrade hazard rates by borrower-type, estimated using OLS. Treatment (control) borrowers are those with total debt between $\$ 150,000$ and $\$ 200,000(\$ 200,000$ and $\$ 250,000)$ during the pre-announcement period (January to March 1998). The dependent variable, downgrade, is from rating $=1$ to rating $=2$. The sample is all treatment and control borrowers with a single lending relationship and with a rating of one in the preannouncement period. The unit of observation is at the borrower-bank-month level. Characteristic denotes whether the borrower is a large borrower (Columns (1) and (2)) or urban borrower (Columns (3) and (4)), or whether the lender faces low competition (Columns (5) and (6)). Large borrowers is an indicator variable equal to one if the borrower size classification is equal or greater than three ( $>25$ employees); urban is an indicator variable equal to one if the borrower is located in the capital city of each state; and local is an indicator variable equal to one if the lender is a local bank. Low competition is measured as the ratio of the total number of borrowers over the total number of branches for each lender at the state level. Local is an indicator variable equal to one if the lender is a local bank. We omit from reporting the coefficient estimates of Treated $\times$ Characteristic, Interim $\times$ Characteristic in all columns; Treated $\times$ Local, Interim $\times$ Local, Treated $\times$ Local $\times$ Characteristic, Interim $\times$ Local $\times$ Characteristic in Columns (2) and (4). Borrower controls include $\log (\mathrm{debt})$, state, and industry classification in all columns plus urban in Columns (1) and (2), $\log (\mathrm{debt})$ in Columns (3) and (4), and urban and $\log (\mathrm{debt})$ in Columns (5) and (6). Standard errors are clustered at the borrower level. *, **, and *** indicate statistical significance at the $10 \%, 5 \%$, and $1 \%$ level.

in the pre-announcement period. ${ }^{14}$ This effect is unlikely to be driven by business cycles because it is present only for treated borrowers, that is, for the borrowers whose credit ratings become public for the first time, and not for the borrowers with slightly bigger total loan amounts. Also, a higher exposure to the approaching Argentinian recession would imply that treatment borrowers with a rating of two should be more, not less likely to default. $^{15}$

14 In Table IA.6 of the Internet Appendix, we also find that borrowers in the treatment group that are downgraded in the interim period are not more likely to default than treated borrowers with a rating of one that were not downgraded, further supporting our interpretation that most of the downgrades of treatment group borrowers in the interim period were not driven by the arrival of new information.

15 The conclusion that downgrades are driven by information manipulation rather than by the arrival of new information is also consistent with the finding that banks, on average, do not change the amount of the loan in the interim period (see Table IA.7 for single-lender borrowers and Table IA. 8 for multiple lender borrowers). 
The Review of Financial Studies / v 0 n 02017

Table 5

Information sharing and credit rating informativeness

A

\begin{tabular}{|c|c|c|}
\hline \multirow{3}{*}{$\begin{array}{l}\text { Dependent variable } \\
\text { Sample lender }\end{array}$} & \multicolumn{2}{|c|}{ Default } \\
\hline & \multicolumn{2}{|c|}{ Single and rating $=2$} \\
\hline & (1) & (2) \\
\hline Default horizon & 6 Mths & 12 Mths \\
\hline Treated & $\begin{array}{c}-0.014 \\
(0.102)\end{array}$ & $\begin{array}{c}-0.084 \\
(0.122)\end{array}$ \\
\hline Treated $\times$ Pre & $\begin{array}{c}0.273^{* *} \\
(0.109)\end{array}$ & $\begin{array}{c}0.175^{*} \\
(0.100)\end{array}$ \\
\hline Bank controls & Yes & Yes \\
\hline Borrower controls & Yes & Yes \\
\hline Time fixed effects & Yes & Yes \\
\hline Bank fixed effects & Yes & Yes \\
\hline Industry fixed effects & Yes & Yes \\
\hline No. observations & 768 & 435 \\
\hline R-sq. & 0.34 & 0.43 \\
\hline \multicolumn{3}{|l|}{$B$} \\
\hline Dependent variable & \multicolumn{2}{|c|}{ Default } \\
\hline \multirow[t]{2}{*}{ Sample lender } & \multicolumn{2}{|c|}{ Single and rating = 1} \\
\hline & (1) & (2) \\
\hline Default horizon & 6 Mths & 12 Mths \\
\hline Treated & $\begin{array}{c}0.001 \\
(0.021)\end{array}$ & $\begin{array}{c}0.009 \\
(0.034)\end{array}$ \\
\hline Treated $\times$ Pre & $\begin{array}{c}0.017 \\
(0.030)\end{array}$ & $\begin{array}{c}0.010 \\
(0.028)\end{array}$ \\
\hline Bank controls & Yes & Yes \\
\hline Borrower controls & Yes & Yes \\
\hline Time fixed effects & Yes & Yes \\
\hline Bank fixed effects & Yes & Yes \\
\hline Industry fixed effects & Yes & Yes \\
\hline No. observations & 7,387 & 4,238 \\
\hline R-sq. & 0.15 & 0.25 \\
\hline
\end{tabular}

This table presents the difference-in-differences effect of the credit rating in the pre-announcement period on default hazard rates for borrowers with a rating $=2$, estimated using OLS. Treatment (control) borrowers are those with total debt between $\$ 150,000$ and $\$ 200,000(\$ 200,000$ and $\$ 250,000)$ during the pre-announcement period (January to March 1998). The dependent variable, default, is an indicator variable equal to one if the borrower defaults in the subsequent six-month period in Column (1) or 12-month period in Column (2). In panel A, the sample is all treatment and control borrowers with a single lending relationship in the pre-announcement period and with a rating $=2$ in the current period. In panel $\mathrm{B}$, the sample is all treatment and control borrowers with a single lending relationship in the pre-announcement period and with a rating $=1$ in the current period. The unit of observation is at the borrower-bank-month level. Bank controls include log(total assets), return on assets, capitalization $(\%), \log ($ number of branches), nonperforming loans-to-total assets, deposits-to-total assets, and growth on total assets, while borrower controls include the $\log (\mathrm{debt})$, state, size, and urban. Standard errors are clustered at the borrower level. *,**, and *** indicate statistical significance at the $10 \%, 5 \%$, and $1 \%$ level.

One may also wonder whether banks just downgrade marginal borrowers, perhaps slightly changing the internal cutoff for different ratings. While this behavior would be consistent with manipulation, it may make the results less striking and also less relevant from a policy point of view. If banks just downgraded marginal borrowers, the pool of borrowers rated one should have lower default rates post-manipulation because the worse borrowers are now 
rated 2. In panel B of Table 5, we find no evidence that this is the case, suggesting that the downgrades affect not only marginal borrowers but also the best quality borrowers that are rated one, comfortably above the cutoff.

Taken together, the results in panels A and B of Table 5 imply that default rates converge for treatment group borrowers with ratings of one or two in the period of the credit registry expansion. Put differently, we find that the ratings of treatment group borrowers become less informative even after we include bank and borrower controls, and industry, bank and time fixed effects. Thus, the downgrades cannot be driven by the incorporation of more precise information in the ratings before their public release, because in that case ratings should become more, not less precise in predicting defaults.

Overall, these findings fully support the conjecture that banks manipulate the credit ratings in order to protect their informational rents.

\subsection{Strategic upgrades of low-quality borrowers with multiple bank relationships}

Lenders to low-quality borrowers with multiple lenders may fear that the public revelation of negative information to other lenders will cause a creditor run and the ultimate default of the borrower. If this occurred, the bank revealing negative information would suffer because the loan would be less likely to be repaid. Therefore, banks may have an incentive to strategically upgrade multiple-lender borrowers with a rating of two.

This is precisely what we find when we estimate the probability that a borrower is upgraded from two to one in the multiple-lender subsample. Table 6 presents the results. Treatment borrowers, defined as borrowers that maintain a rating of two and total loans below the $\$ 200,000$ threshold in the period preceding the announcement of the credit registry expansion, are more likely to be upgraded in the interim period in comparison to borrowers in the control sample, whose credit ratings were already public. The magnitude of the effects in Column 1 is 8.9 percentage points. This magnitude is large compared with the unconditional propensity to upgrade for this subsample of borrowers of 0.19 overall and 0.16 in the pre-announcement period. The effect is almost double in Column 2 once we include borrower fixed effects. ${ }^{16}$ Consistent with our identification assumption, the abnormal propensity to upgrade treatment borrowers with multiple lenders exists in the interim period, but not in the post-period.

Our argument that banks strategically upgrade borrowers with multiple lenders to avoid creditor runs does not hinge on lenders' private information. Observing a negative rating, other lenders may revise upwards the probability that the bank with negative rating will withdraw credit. We would therefore expect all banks, not only local banks, to strategically upgrade their borrowers. This is precisely what we find in Columns 3 and 5 .

16 We include borrower fixed effects in the multiple lender sample to mitigate the concern that our results are due to a handful of borrowers being upgraded by multiple lenders. 
Table 6

Strategic upgrades of low-quality borrowers by multiple lenders

\begin{tabular}{|c|c|c|c|c|c|c|c|}
\hline \multirow{3}{*}{$\begin{array}{l}\text { Dependent variable } \\
\text { Sample lender }\end{array}$} & \multicolumn{7}{|c|}{ Upgrades from 2 to 1} \\
\hline & \multicolumn{6}{|c|}{ Multiple } & \multirow{2}{*}{$\frac{3 \text {-month pos }}{(7)}$} \\
\hline & (1) & (2) & (3) & (4) & (5) & (6) & \\
\hline Treated & $\begin{array}{r}-0.030 \\
(0.022)\end{array}$ & & & & & & \\
\hline Treated $\times$ Interim & $\begin{array}{r}0.089^{*} \\
(0.051)\end{array}$ & $\begin{array}{l}0.152^{* *} \\
(0.064)\end{array}$ & $\begin{array}{l}0.209^{* *} \\
(0.071)\end{array}$ & $\begin{array}{r}0.162^{*} \\
(0.094)\end{array}$ & $\begin{array}{l}0.222^{* * *} \\
(0.111)\end{array}$ & $\begin{array}{l}0.147^{* *} \\
(0.061)\end{array}$ & $\begin{array}{l}0.180^{* *} \\
(0.074)\end{array}$ \\
\hline Treated $\times$ Post & & & $\begin{array}{c}0.096 \\
(0.064)\end{array}$ & & $\begin{array}{c}0.103 \\
(0.099)\end{array}$ & & \\
\hline Treated $\times$ Interim $\times$ Local & & & & $\begin{array}{r}-0.034 \\
(0.130)\end{array}$ & $\begin{array}{r}-0.041 \\
(0.148)\end{array}$ & & \\
\hline Treated $\times$ Post $\times$ Local & & & & & $\begin{array}{c}-0.014 \\
(0.125)\end{array}$ & & \\
\hline Bank controls & Yes & Yes & Yes & Yes & Yes & No & No \\
\hline Borrower controls & Yes & Yes & Yes & Yes & Yes & Yes & Yes \\
\hline Time fixed effects & Yes & Yes & Yes & Yes & Yes & No & No \\
\hline Bank fixed effects & Yes & Yes & Yes & Yes & Yes & No & No \\
\hline Industry fixed effects & Yes & Yes & Yes & Yes & Yes & No & No \\
\hline Borrower fixed effects & No & Yes & Yes & Yes & Yes & Yes & Yes \\
\hline Bank-time fixed effects & No & No & No & No & No & Yes & Yes \\
\hline Industry-time fixed effects & No & No & No & No & No & Yes & Yes \\
\hline No. observations & 2,365 & 2,365 & 2,365 & 2,365 & 2,365 & 2,365 & 1,240 \\
\hline R-sq. & 0.11 & 0.36 & 0.36 & 0.36 & 0.36 & 0.66 & 0.59 \\
\hline
\end{tabular}

This table presents the difference-in-differences effect of the registry expansion announcement (interim period) and public information (post-expansion period) on upgrade hazard rates, estimated using OLS. Treatment (control) borrowers are those with total debt between $\$ 150,000$ and $\$ 200,000(\$ 200,000$ and $\$ 250,000)$ during the pre-announcement period (January to March 1998). The dependent variable, upgrade, is from rating $=2$ to rating $=1$ (best). The sample is all treatment and control borrower-bank relationships with a rating $=1$ in the pre-announcement period for borrowers with multiple lending relationships in the pre-announcement period. Columns (1) to (6) use a 12-month post-period horizon, while Column (7) uses a three-month post-period horizon. Local is an indicator variable equal to one if the lender is a local bank. The unit of observation is at the borrower-bank-month level. Bank controls include log(total assets), return on assets, capitalization (\%), $\log$ (number of branches), nonperforming loans-to-total assets, deposits-to-total assets, and growth on total assets, while borrower controls include the $\log (\mathrm{debt})$, state, size, industry classification, and urban. Standard errors are clustered at the borrower level. *,**, and *** indicate statistical significance at the $10 \%, 5 \%$, and $1 \%$ level.

Finally, the strategic upgrades are not driven by bank or industry-specific shocks as the results in Column 6 are robust to the inclusion of bank-time and industry-time fixed effects. Column 7 further shows that our results are robust when we use a three-month post-period.

Table IA.9 in the Internet Appendix provides futher robustness tests. If the upgrades are indeed driven by fear that the revelation of negative information may induce a creditor run, we should not observe a similar effect for borrowers with which the bank entertains an exclusive relationship. This is precisely what we find in Column 1. This is comforting because it further assuages concerns that treated borrowers with a rating of 2 may be subject to positive shocks.

The finding in Column 1 is also important to dispel concerns that changes in credit ratings are due to a systematic revision of all credit ratings aiming to update information about the borrowers before sharing it with other financial institutions. If the changes in ratings we observe were driven by a mere incorporation of new information, we should observe that banks also upgrade 
some borrowers with whom they entertain single relationships. The fact that this is not the case (together with our earlier evidence that cross-sectional differences are consistent with theoretical predictions and the finding that credit ratings become less informative) indicates that changes in ratings are not driven by systematic revisions, but are instead strategic.

The rest of Table IA.9 presents a subsample analysis mimicking the one in Table IA.5. The results in Columns 2 to 5 fully support our identifying assumption. In Column 2, where we use a smaller set of borrowers around the cutoff, thus limiting unobserved heterogeneity, the coefficient of Treated $\times$ Interim $_{t}$ increases with respect to the benchmark specification in Column 6 of Table 6. The contrary is true in Column 3, where we use a larger set of borrowers around the cutoff. Also, the effect of Treated $_{i} \times$ Interim $_{t}$ is not statistically significant in the placebo tests, presented in Columns 4 and 5, where borrowers with loan amounts strictly below and strictly above the cutoff are considered in the estimation.

Consistent with the interpretation that the upgrades of low-quality borrowers are strategic, panel A of Table 7 shows that the subsample of borrowers with multiple lenders and a credit rating of one was better quality before the announcement of the reform. Treatment group borrowers with a rating of one have a lower probability of future default before the announcement of the credit registry expansion than treatment group borrowers receiving the same rating in the interim or the post-period, relative to the control group. ${ }^{17}$ Thus, while the subsample of single-lender borrowers with a rating of two becomes relatively better and the quality of single-lender borrowers with a rating of one is invariant, the subsample of multiple-lender borrowers with a rating of one becomes relatively worse.

Panel B of Table 7 explores whether the upgraded borrowers are marginal borrowers. If the borrowers upgraded from the pools of twos were the relatively better ones, the quality of multiple-lender borrowers with a rating of two should decline post-manipulation. We find that the quality of borrowers of multiple lenders with a rating of two is unchanged, on average, suggesting once again that strategic upgrades occur across the board. ${ }^{18}$

This evidence parallels the findings on the probability of default in the single borrower sample. There is a convergence in the probability of default of borrowers with one and two ratings also in the multiple-lender subsample as multiple-lender borrowers with a rating of one were less likely to default in the pre-announcement period. Thus, also in this subsample ratings become less informative.

17 Also, multiple-lender borrowers upgraded in the interim period are, on average, as likely to default as borrowers that have not been upgraded, and the size of their loans remain unchanged.

18 Only the quality of single-lender borrowers with a rating of two improves after the reform, as shown in panel A of Table 5. 
The Review of Financial Studies / v 0 n 02017

Table 7

Informativeness of multiple lenders credit ratings

A

\begin{tabular}{|c|c|c|}
\hline \multirow{3}{*}{$\begin{array}{l}\text { Dependent variable } \\
\text { Sample lender }\end{array}$} & \multicolumn{2}{|c|}{ Default } \\
\hline & \multicolumn{2}{|c|}{ Multiple and rating $=1$} \\
\hline & (1) & (2) \\
\hline Default horizon & 6 Mths & 12 Mths \\
\hline Treated & $\begin{array}{c}0.020 \\
(0.015)\end{array}$ & $\begin{array}{c}0.032 \\
(0.022)\end{array}$ \\
\hline Treated $\times$ Pre & $\begin{array}{c}-0.033^{* *} \\
(0.016)\end{array}$ & $\begin{array}{r}-0.025^{*} \\
(0.015)\end{array}$ \\
\hline Bank controls & Yes & Yes \\
\hline Borrower controls & Yes & Yes \\
\hline Time fixed effects & Yes & Yes \\
\hline Bank fixed effects & Yes & Yes \\
\hline Industry fixed effects & Yes & Yes \\
\hline No. observations & 23,539 & 13,355 \\
\hline R-sq. & 0.07 & 0.11 \\
\hline \multicolumn{3}{|l|}{$B$} \\
\hline Dependent variable & \multicolumn{2}{|c|}{ Default } \\
\hline \multirow[t]{2}{*}{ Sample lender } & \multicolumn{2}{|c|}{ Multiple and rating $=2$} \\
\hline & (1) & (2) \\
\hline Default horizon & 6 Mths & 12 Mths \\
\hline Treated & $\begin{array}{c}0.015 \\
(0.046)\end{array}$ & $\begin{array}{c}0.017 \\
(0.072)\end{array}$ \\
\hline Treated $\times$ Pre & $\begin{array}{c}-0.025 \\
(0.066)\end{array}$ & $\begin{array}{r}-0.070 \\
(0.077)\end{array}$ \\
\hline Bank controls & Yes & Yes \\
\hline Borrower controls & Yes & Yes \\
\hline Time fixed effects & Yes & Yes \\
\hline Bank fixed effects & Yes & Yes \\
\hline Industry fixed effects & Yes & Yes \\
\hline No. observations & 1,700 & 924 \\
\hline Adj. R-sq. & 0.178 & 0.15 \\
\hline
\end{tabular}

This table presents the difference-in-differences effect of the credit rating in the pre-announcement period on default hazard rates for borrowers with a credit rating of 1, estimated using OLS. Treatment (control) borrowers are those with total debt between $\$ 150,000$ and $\$ 200,000(\$ 200,000$ and $\$ 250,000)$ during the pre-announcement period (January to March 1998). The dependent variable, Default, is an indicator variable equal to one if the borrower's credit rating worsens in the subsequent six-month period in Column (1) or 12-month period in Column (2). In panel A, the sample is all treatment and control borrowers with a multiple lending relationships in the pre-announcement period and with a rating $=1$ in the current period. In panel B, the sample is all treatment and control borrowers with a multiple lending relationships in the pre-announcement period and with a Rating = 2 in the current period. Bank controls include $\log$ (total assets), return on assets, capitalization (\%), $\log$ (number of branches), nonperforming loans-to-total assets, deposits-to-total assets, and growth on total assets, while borrower controls include the $\log (\mathrm{debt})$, state, size, and urban. The unit of observation is at the borrower-bankmonth level. Standard errors are clustered at the borrower level. *,**, and $* * *$ indicate statistical significance at the $10 \%, 5 \%$, and $1 \%$ level.

Taken jointly, our findings are fully consistent with the banks' incentives to manipulate information with the ultimate goal of maximizing their net wealth and are difficult to explain with shocks affecting the treated borrowers but not the control borrowers. For our results to be driven by negative shocks, it would have to be that single-lender treatment borrowers with an initial rating 
of one are more exposed to negative shocks than control borrowers, while the contrary would have to hold for multiple-lender treatment borrowers with an initial rating of two. This seems implausible given that treatment and control are based on the same total outstanding loan threshold in the two subsamples.

\subsection{Implications of information sharing on bank-borrower relationships}

So far we have shown that banks strategically manipulate the ratings they can discretionally assign to borrowers before sharing them in a way that is consistent with their incentives. As a consequence, credit ratings become less informative once it is known that they will be shared with other banks. This implies that only garbled information is revealed. Is this information sufficiently informative to affect bank-borrower relationships and the structure of loan contracts?

Table 8 provides some evidence on the effects of information sharing on the structure of bank-borrower relationships. We estimate how the release of public information affects the total debt and the composition of bank relationships on the intensive and extensive margins in the post-reform period. For borrowers in the treatment and control groups, we examine the number of bank relationships and composition of debt by bank type across all relationships, not just those that existed prior to the registry expansion. Panel A concentrates on borrowers that had a single lender at the beginning of the sample period. The within-borrower estimation results show that, on average, the total debt (Column 1) and the number of relationships (Column 2) do not change.

However, following the credit registry expansion, the fraction of debt provided by local banks to treatment borrowers decreases (Column 3), and the fraction of debt provided by foreign banks increases (Column 4). Prior to the expansion of the credit registry, on average, treatment borrowers sourced $63 \%$ of loans from local banks, while control borrowers, whose information was already public, sourced just $41 \%$. In contrast, treatment borrowers sourced just $16 \%$ of debt from foreign banks, while control borrowers sourced $30 \%$. Post-expansion, foreign banks provided treatment borrowers $18 \%$ and control borrowers $29 \%$ of their debt. Consequently, the results in Columns 3 and 4 in panel A of Table 8 imply that the credit registry expansion provided greater access to foreign funding, and that treated borrowers shifted debt away from local lenders.

In Columns 3 and 4, we omit borrower fixed effects as there is very little within-borrower variation in the composition of lenders over our short time window. Nonetheless, we find similar results in Column 5 when we estimate the within-borrower effect of public information about local bank lending.

One of the greatest frictions to new bank entry is adverse selection. This friction is aggravated for transaction lenders, such as foreign banks. If the credit registry mitigates this friction, we should observe that the decrease in local bank lending (and increase in foreign bank lending) should be concentrated in borrowers with the best credit ratings. Consistent with this, we split the sample of single-lender borrowers based on whether the borrower has a credit rating 
Table 8

Information sharing and changes in bank lending relationships

A

\begin{tabular}{|c|c|c|c|c|c|c|c|}
\hline \multirow{3}{*}{$\begin{array}{l}\text { Sample } \\
\text { Dependent variable }\end{array}$} & \multicolumn{7}{|c|}{ Single lender } \\
\hline & \multicolumn{5}{|c|}{ All borrowers } & \multirow{2}{*}{$\begin{array}{c}\text { Rating }=1 \\
\% \text { local } \\
(6)\end{array}$} & \multirow{2}{*}{$\begin{array}{c}\text { Rating }>1 \\
\% \text { local } \\
(7)\end{array}$} \\
\hline & $\underset{(1)}{\log (\text { total debt })}$ & $\begin{array}{c}\log (\# \text { \#anks }) \\
(2)\end{array}$ & $\begin{array}{l}\% \text { local } \\
\text { (3) }\end{array}$ & $\begin{array}{l}\% \text { foreign } \\
\text { (4) }\end{array}$ & $\begin{array}{l}\% \text { local } \\
\text { (5) }\end{array}$ & & \\
\hline Treated $\times$ Post & $\begin{array}{c}0.021 \\
(0.064)\end{array}$ & $\begin{array}{c}-0.017 \\
(0.025)\end{array}$ & $\begin{array}{l}-0.032^{* *} \\
(0.015)\end{array}$ & $\begin{array}{l}0.026^{*} \\
(0.015)\end{array}$ & $\begin{array}{r}-0.015^{*} \\
(0.009)\end{array}$ & $\begin{array}{r}-0.017^{*} \\
(0.010)\end{array}$ & $\begin{array}{r}-0.005 \\
(0.005)\end{array}$ \\
\hline Borrower controls & Yes & Yes & Yes & Yes & Yes & Yes & Yes \\
\hline Borrower fixed effects & Yes & Yes & No & No & Yes & Yes & Yes \\
\hline $\begin{array}{l}\text { Industry-time } \\
\text { fixed effects }\end{array}$ & Yes & Yes & Yes & Yes & Yes & Yes & Yes \\
\hline No. observations & 11,698 & 11,698 & 11,698 & 11,698 & 11,698 & 9,737 & 1,961 \\
\hline R-Sq. & 0.57 & 0.68 & 0.44 & 0.24 & 0.99 & 0.99 & 0.99 \\
\hline \multicolumn{8}{|l|}{$b$} \\
\hline \multirow[t]{3}{*}{ Sample } & \multicolumn{7}{|c|}{ Multiple lender } \\
\hline & \multicolumn{5}{|c|}{ All borrowers } & Rating $=1$ & Rating $>1$ \\
\hline & $\begin{array}{c}\log (\text { total debt }) \\
\text { (1) }\end{array}$ & $\begin{array}{c}\log (\# \text { banks }) \\
(2)\end{array}$ & $\begin{array}{l}\% \text { local } \\
\text { (3) }\end{array}$ & $\begin{array}{l}\% \text { foreign } \\
\text { (4) }\end{array}$ & $\begin{array}{c}\% \text { local } \\
\text { (5) }\end{array}$ & $\begin{array}{l}\% \text { local } \\
\text { (6) }\end{array}$ & $\begin{array}{l}\% \text { local } \\
\text { (7) }\end{array}$ \\
\hline Treated $\times$ Post & $\begin{array}{c}0.009 \\
(0.038)\end{array}$ & $\begin{array}{l}0.044^{* *} \\
(0.018)\end{array}$ & $\begin{array}{r}-0.006 \\
(0.010)\end{array}$ & $\begin{array}{c}0.009 \\
(0.011)\end{array}$ & $\begin{array}{l}-0.008 \\
(0.008)\end{array}$ & $\begin{array}{r}-0.006 \\
(0.008)\end{array}$ & $\begin{array}{r}-0.002 \\
(0.023)\end{array}$ \\
\hline Borrower controls & Yes & Yes & Yes & Yes & Yes & Yes & Yes \\
\hline Borrower fixed effects & Yes & Yes & No & No & Yes & Yes & Yes \\
\hline $\begin{array}{l}\text { Industry-time } \\
\text { fixed effects }\end{array}$ & Yes & Yes & Yes & Yes & Yes & Yes & Yes \\
\hline No. observations & 18,838 & 18,838 & 18,838 & 18,838 & 18,838 & 16,534 & 2,304 \\
\hline R-sq. & 0.58 & 0.79 & 0.411 & 0.231 & 0.97 & 0.97 & 0.98 \\
\hline
\end{tabular}

This table presents the difference-in-differences effect of public information (post-expansion period) on bank lending-relationships. Treatment (control) borrowers are those with total debt between $\$ 150,000$ and $\$ 200,000$ (\$200,000 and \$250,000) during the pre-announcement period (January to March 1998). In panels A and $\mathrm{B}$, the sample is all treatment and control borrowers with single and multiple lending relationships in the pre-announcement period, respectively. Dependent variables are the $\log ($ total debt), the number of lending relationships $(\log (\#$ \#anks)), the fraction of lending relationships that are with local banks (\% local), which reflect relationship banks, and the fraction of lending relationships that are with foreign banks (\% foreign) which reflect transactional banks. The unit of observation is at the borrower-bank-month level. Columns (1) to (5) include all borrowers; Column (6) includes borrowers that maintain a rating that equals one with all lenders; and Column (7) includes those borrowers with at least one rating greater than one. Borrower controls include the state, size, industry classification, and urban in Column (1) and log(total debt), state, size, industry classification, and urban in Columns (2)-(7). The unit of observation is at borrower-month level. Standard errors are clustered at the borrower level. *,**, and *** indicate statistical significance at the $10 \%, 5 \%$, and $1 \%$ level.

of one (Column 6) or greater than one (Column 7) and find that the shift in borrowing away from local lenders is concentrated in the best borrowers.

Panel B concentrates on borrowers that had multiple bank relationships at the beginning of the sample period. It appears that these borrowers are able to start new relationships (Column 2). Possibly because the level of information asymmetry was lower for borrowers that already engaged multiple banks in the pre-announcement period, it does not appear that foreign banks take great advantage of the public credit registry, as the share of loans provided by foreign banks and by local banks does not change post-registry expansion. 
Table 9

Information manipulation and changes in bank lending relationships

Sample

Single lender

\begin{tabular}{lcccc} 
& \multicolumn{3}{c}{ Treatment borrowers w/rating $=1$ in the pre-period } \\
\cline { 2 - 5 } Dependent variable & $\begin{array}{c}\log (\text { total debt }) \\
(1)\end{array}$ & $\log ($ \#banks $)$ & $\%$ local & $\begin{array}{c}\% \text { foreign } \\
(4)\end{array}$ \\
\hline Downgraded $\times$ Post & 0.055 & $-0.130^{*}$ & $0.021^{* *}$ & $-0.017^{*}$ \\
& $(0.176)$ & $(0.070)$ & $(0.010)$ & $(0.009)$ \\
Borrower controls & Yes & Yes & Yes & Yes \\
Borrower fixed effects & Yes & Yes & No & No \\
Industry-time fixed effects & Yes & Yes & Yes & Yes \\
No. observations & 2,092 & 2,092 & 2,092 & 2,092 \\
R-sq. & 0.57 & 0.77 & 0.98 & 0.96 \\
\hline
\end{tabular}

This table presents the difference-in-differences effect of public information (post-expansion period) on bankrelationships for those borrowers that were strategically downgraded. Treatment borrowers are those with total debt between $\$ 150,000$ and $\$ 200,000$ during the pre-announcement period (January to March 1998). The sample is all treatment borrowers with single lending relationships and a rating that equals one in the pre-announcement period. Dependent variables are the $\log ($ total debt), the number of relationships $(\log (\#$ banks)), the fraction of lending relationships that are with local banks (\% local), which reflect relationship banks, and the fraction of lending relationships that are with foreign banks (\% foreign). The unit of observation is at the borrower-bankmonth level. Borrower controls include the state, size, industry classification, and urban in Column (1) and $\log ($ total debt), state, size, industry classification, and urban in Columns (2)-(4). The unit of observation is at borrower-month level. Standard errors are clustered at the borrower level. *, **, and *** indicate statistical significance at the $10 \%, 5 \%$, and $1 \%$ level.

These results indicate that the public credit registry increases bank competition for lending to borrowers not previously included in the registry. The competition takes the form of more credit from foreign banks for borrowers with single lenders. The number of bank relationships of multiple-lender borrowers also increases.

While overall the credit registry expansion may have advantaged transaction banks at the expense of relationship banks, the strategic downgrades appear to have been effective in preserving some of the rents of relationship banks. This is evident in Table 9, which reproduces the results in panel A of Table 8 for the subsample of treated borrowers that had a rating of one in the preannouncement period. The interaction term Downgraded D $_{i}$ Post $_{t}$ shows that for borrowers that have been strategically downgraded in the interim period the effects are opposite to the ones in panel A of Table 8. Downgraded borrowers do not start new relationships at the same rate as nondowngraded borrowers, which may explain why we find no effect on the number of new relationships in panel A of Table 8. Strategically downgraded borrowers become more, not less, dependent on local banks and receive less credit from foreign banks after their ratings become public, indicating that rating manipulation impacts the allocation of credit. ${ }^{19}$

19 Focusing on borrowers with multiple relationships and a rating of two in the pre-announcement period, we find that the total loans of borrowers that have not been upgraded in the interim period decrease in the post-period. This decrease suggests that a creditor run occurs for these borrowers and matches the findings of Hertzberg, Liberti and Paravisini (2011). This finding also suggests that strategic upgrades achieve their objective of avoiding a creditor run. 


\section{Conclusion}

We have provided evidence that banks manipulate credit ratings before sharing them because of the extension of a public credit registry. Our findings are important for the design of public credit registries. Policy makers often use these tools for supervision, as well as for attempting to limit asymmetric information between lenders and between borrowers and lenders. We highlight that making borrowers' rating public to other lenders may negatively affect the quality of the information available for supervision.

Our findings are even more relevant in light of a debate on the design of public credit registries that has accompanied the implementation of Basel II. While the credit ratings that banks share with other lenders in public credit registries typically are not the internal credit ratings used for Basel II capital requirements, the possibility of sharing internal credit ratings has been widely discussed (see, for instance, Powell et al. 2004; Hertig 2006).

Our results imply that such regulation could reinforce the incentives to report manipulated ratings in a way that varies over the business cycles. To the extent that fears of creditor runs are stronger when capital requirements are binding and lending standards are expected to tighten, regulation requiring lenders to share borrowers' internal ratings would strengthen banks' incentives to strategically upgrade borrowers with multiple lenders.

In normal times, banks are willing to hold levels of capital well above regulatory minimums (Flannery and Rangan 2008; Gropp and Heider 2010; Allen, Carletti, and Marquez 2011). Even if the ratings shared in the registry were the same as those used for Basel II, banks would still have an incentive to strategically downgrade good borrowers if the capital requirements are not binding. This is most likely during good times, when competitors are likely to expand their loan portfolio and competition in the credit market is stronger.

Our findings are also important for the growing debate on the use of credit ratings following the 2007-2009 financial crisis. Existing literature indicates the limitations arising from the issuer-pays model. We show that ratings are manipulated in a situation in which the rater is the lender. This result has implications for alternative models to disseminate information in financial markets that have been considered after the financial crisis.

Following the enactment of the Dodd-Frank Act, insurance companies obtain regulator-paid expected loss assessments from PIMCO and BlackRock to compute their capital requirements. If PIMCO or BlackRock increase the expected loss assessment, insurance companies are likely to sell in the same way as creditors may withdraw their loans after observing a not so good rating. Since PIMCO and Blackrock invest themselves in the securities they assess, an increase in the expected loss assessment could prompt sales and negatively feedback on the valuations of their holdings. Our results imply that this alternative model to disseminate information is not immune from conflicts 
of interest because agents will behave strategically if they expect information disclosure to feedback on their profits.

An important area of research would be to understand whether the incentives to manipulate, which we have highlighted, are at work outside the banking industry and public credit registries.

\section{References}

Allen, F., E. Carletti, and R. Marquez. 2011. Credit market competition and capital regulation. Review of Financial Studies 24:983-1018.

Begley, T. A., A. K. Purnanandam, and K. C. Zheng. 2015. The strategic under-reporting of bank risk, Working Paper, University of Michigan.

Berger, A. N., N. H. Miller, M. A. Petersen, R. G. Rajan, and J. C. Stein. 2005. Does function follow organizational form? Evidence from the lending practices of large and small banks. Journal of Financial Economics 76:237-69.

Bolton, P., X. Freixas, and J. Shapiro. 2012. The credit ratings game. Journal of Finance 67:85-111.

Brown, M., T. Jappelli, and M. Pagano. 2009. Information sharing and credit: Firm-level evidence from transition countries. Journal of Financial Intermediation 18:151-72.

Carey, M. 2012. A guide to choosing absolute bank capital requirements. Journal of Banking and Finance 26:929-51.

Corsetti, G., A. Dasgupta, S. Morris, and H. S. Shin. 2004. Does one soros make a difference? A theory of currency crises with large and small traders. Review of Economic Studies 71:87-113.

Djankov, S., C. Mcliesh, and A. Shleifer. 2007. Private credit in 129 countries. Journal of Financial Economics 84:299-329.

Doblas-Madrid, A., and R. Minetti. 2013. Sharing information in the credit market: Contract-level evidence from US firms. Journal of Financial Economics 109:198-223.

Efing, M., and H. Hau. 2015. Structured debt ratings: Evidence on conflicts of interest. Journal of Financial Economics 116:46-60.

Farinha, L. A., and J. A. C. Santos. 2002. Switching from single to multiple bank lending relationships: Determinants and implications. Journal of Financial Intermediation 11:124-51.

Flannery, M., and K. P. Rangan. 2008. Market forces at work in the banking industry: Evidence from the capital buildup from the 1990s. Review of Finance 12:391-429.

Giannetti, M., and S. Ongena. 2009. Financial Integration and Firm Performance: Evidence from foreign bank entry in emerging markets. Review of Finance 13:181-223.

Gonzales-Uribe, J., and D. Osorio. 2014. Information sharing and credit outcomes: Evidence from a natural experiment. Working Paper, London School of Economics.

Griffin, J. M., J. Nickerson, and D. Y. Tang. 2013. Rating shopping or catering? An examination of the response to competitive pressure for CDO credit ratings. Review of Financial Studies 26:2270-310.

Gropp, R. and F. Heider. 2010. The determinants of bank capital structure. Review of Finance 14:587-622.

Hertig, G. 2006. Basel II and fostering the disclosure of banks' internal credit ratings. European Business Organization Law Review 7:625-46.

Hertzberg, A., J. Liberti, and D. Paravisini. 2011. Public information and coordination: Evidence from a credit registry expansion. Journal of Finance 66:379-412

Ioannidou, V., and S. Ongena. 2010. 'Time for a change': Loan conditions and bank behavior when firms switch banks. Journal of Finance 65:1847-77. 
The Review of Financial Studies / v 0 n 02017

Jappelli, T., and M. Pagano. 2002. Information sharing, lending and defaults: Cross-country evidence. Journal of Banking and Finance 26:2017-45.

Liberti, J., A. Seru, and V. Vig. 2016. Information, credit and organization. Working Paper, University of Chicago

Love, I., and N. Mylenko. 2003. Credit reporting and financing constraints. Working Paper, World Bank Policy Research.

Mian, A. 2006. Distance constraints: The limits of foreign lending in poor economies. Journal of Finance 61:1005-56

Musto, D. K. 2004. What happens when information leaves a market? Evidence from postbankruptcy consumers. Journal of Business 77:725-48.

Ongena, S., and D. C. Smith. 2001. The duration of bank relationships. Journal of Financial Economics 61: 449-475.

Padilla, A. J., and M. Pagano. 1997. Endogenous communication among lenders and entrepreneurial incentives. Review of Financial Studies 10:205-36.

Pagano, M., and T. Jappelli. 1993. Information sharing in credit markets. Journal of Finance 48:1693-718.

Peria, M. S. M., and S. Singh. 2014. The impact of credit information sharing reforms on firm financing. Working Paper, World Bank.

Plosser, M. C., and J. Santos. 2014. Banks' incentives and the quality of internal risk models. Working Paper, Federal Reserve of New York.

Powell, A., G. Majnoni, M. Miller, and N. Mylenko. 2004. Improving credit information, bank regulation and supervision. Working Paper, World Bank Policy Research.

Rajan, R., 1992, Insiders and outsiders: The choice between informed and arm's length debt. Journal of Finance 47:1367-400.

Rajan, U., A. Seru, and V. Vig. 2010. Statistical default models and incentives. American Economic Review 100:506-10.

2015. The failure of models that predict failure: Distance, incentives, and defaults. Journal of Financial Economics 115:237-60.

Schenone, C. 2010. Lending relationships and information rents: Do banks exploit their information advantage? Review of Financial Studies 23:1149-99.

Sharpe, S. A. 1990. Asymmetric information, bank lending and implicit contracts: A stylized model of customer relationships. Journal of Finance 45:1069-87.

Sutherland, A. 2015. The economic consequences of borrower information sharing: Relationship dynamics and investment. Working Paper, University of Chicago. 